\title{
WestVirginiaUniversity
}

THE RESEARCH REPOSITORY @ WVU

Graduate Theses, Dissertations, and Problem Reports

2013

\section{Management Structure Impact on Economic Success of Farmers Markets}

H. R. Scott

West Virginia University

Follow this and additional works at: https://researchrepository.wvu.edu/etd

\section{Recommended Citation}

Scott, H. R., "Management Structure Impact on Economic Success of Farmers Markets" (2013). Graduate Theses, Dissertations, and Problem Reports. 186.

https://researchrepository.wvu.edu/etd/186

This Dissertation is protected by copyright and/or related rights. It has been brought to you by the The Research Repository @ WVU with permission from the rights-holder(s). You are free to use this Dissertation in any way that is permitted by the copyright and related rights legislation that applies to your use. For other uses you must obtain permission from the rights-holder(s) directly, unless additional rights are indicated by a Creative Commons license in the record and/ or on the work itself. This Dissertation has been accepted for inclusion in WVU Graduate Theses, Dissertations, and Problem Reports collection by an authorized administrator of The Research Repository @ WVU.

For more information, please contact researchrepository@mail.wvu.edu. 


\title{
Management Structure Impact on Economic Success of Farmers Markets
}

\author{
H. R. Scott \\ Dissertation submitted to the \\ Davis College of Agriculture, Natural Resources and Design \\ at West Virginia University \\ in partial fulfillment of the requirements \\ for the degree of \\ Doctor of Philosophy \\ in \\ Agricultural and Extension Education
}

\author{
Harry N. Boone, Jr., Ph.D., Chair \\ Deborah A. Boone, Ph.D. \\ Cheryl Brown, Ph.D. \\ Patrick Nestor, Ed.D. \\ Thomas McConnell, M.S.
}

Division of Resource Management

Morgantown, West Virginia

2013

Keywords: Farmers markets, economics, management styles in farmers markets 


\begin{abstract}
Management Structure Impact on Economic Success of Farmers Markets
\end{abstract}

\title{
H.R. Scott
}

Farmers markets have been a part of the food industry in the United States for almost as long as history (Webber, 2010). With farmers markets increasing in popularity and numbers, a need exists to determine why some markets thrive while others fail. A review of literature yielded some regional information however no information specific to West Virginia has been found. The purpose of this study is to determine the role of management has on the economic success of farmers markets in West Virginia. This research uses descriptive correlational research in doing comparison of the management styles in the market and the effect it has on economic profitability. The population for the study was 85 farmers markets and they received a survey of 50 questions. Survey was based on a regional survey by the USDA in 2006 conducted by Ragland and Tropp (2009). The final set of useable surveys consisted of 56 markets for a $65.88 \%$ rate of return. Findings showed that the variables of market management structure, volunteer/paid status of the manager, size of the market, and age of the market did not demonstrate a significant difference between the variables and market economic success. Twenty markets self-reported in the "successful category" (37.7\%). Only 16 of the markets paid their manger with $50 \%$ of these markets paying $\$ 2,000.00$ or less. A majority of the markets were using volunteers for management. A discriminant analysis determined that "years of operation" was the only factor which impacted the "successful" market status. Based on these findings future work needs to be conducted to determine the management structure which is working in the successful markets in West Virginia. 


\section{DEDICATION}

I dedicate this dissertation to my very understanding and wonderful wife for her support and sacrifices made in order for me to have this opportunity. I also dedicate this to Dr.

Jean Woloshuk for her support and guidance as I was working through the various stages of completing this work. 


\section{ACKNOWLEDGEMENTS}

I would like to thank all of those people who helped make this dissertation possible.

To the administrators and colleagues at West Virginia University Extension Service for their support and guidance, to my colleagues at the Monongalia County Extension Office for their understanding with me during this time, and to the office staff that provided support.

To the members of my graduate committee: Dr. Harry N. Boone Jr. for believing in me, guiding me through this research process and for his knowledge and impeccable skill as a statistician and researcher, Dr. Deborah Boone for her attention to details, Dr. Cheryl Brown for knowledge and experience of working with farmers markets, Dr. Patrick Nestor for encouragement and support to pursue this degree, and Thomas McConnell for his knowledge of how farmers markets are being managed in West Virginia. 


\section{TABLE OF CONTENTS}

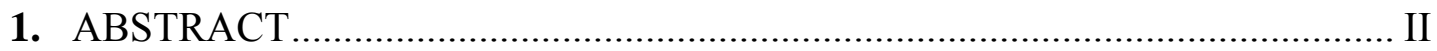

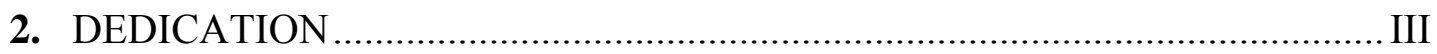

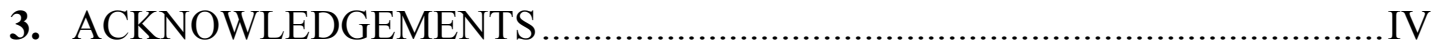

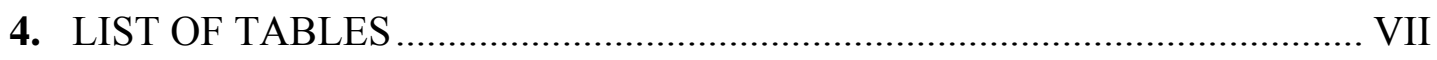

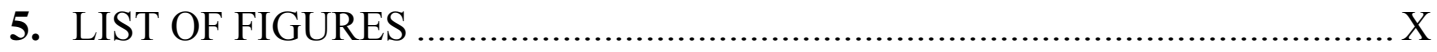

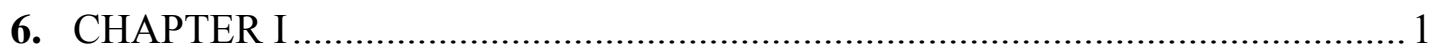

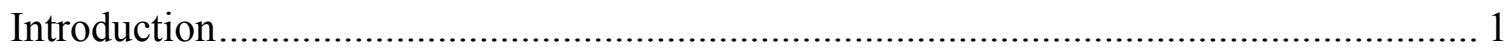

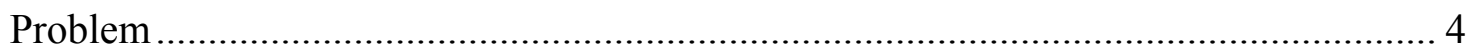

Purpose.

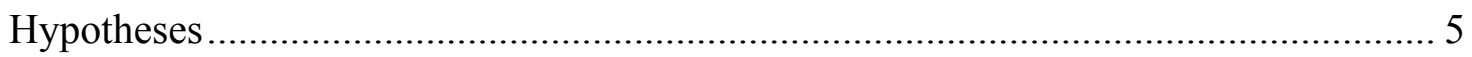

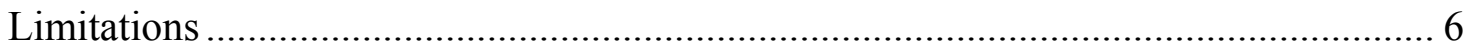

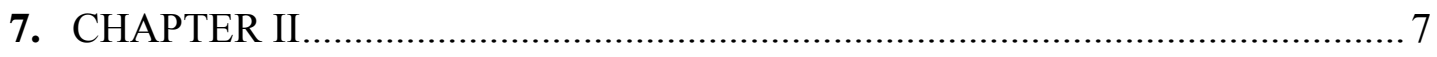

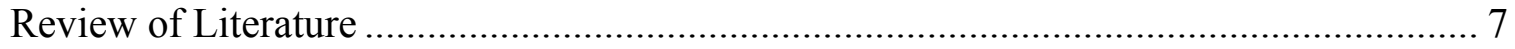

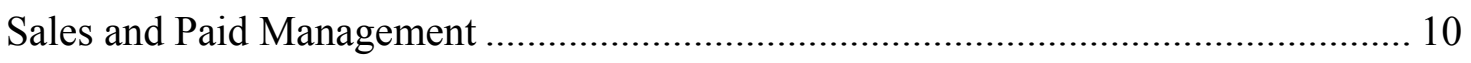

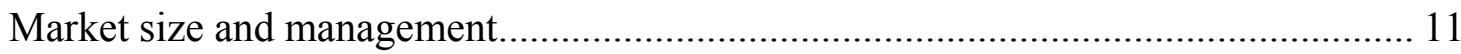

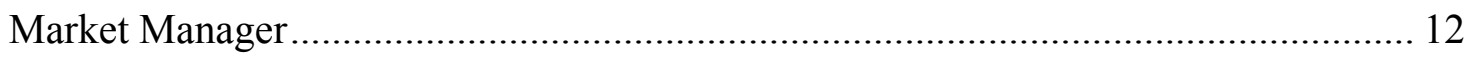

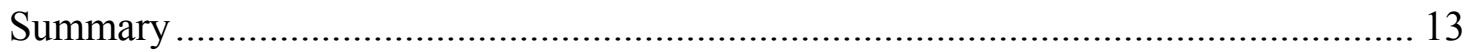

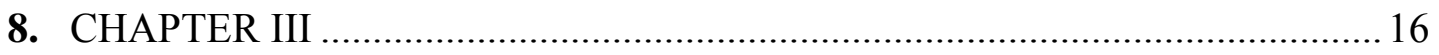

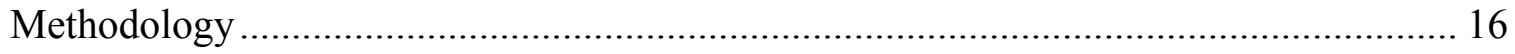

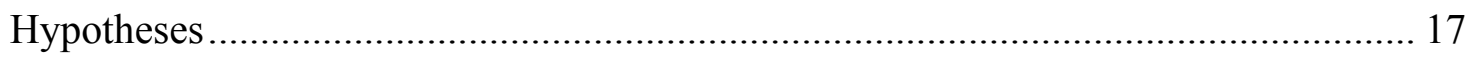

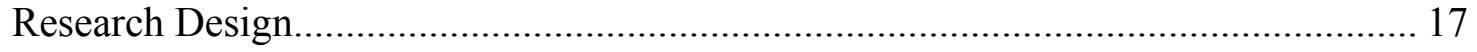

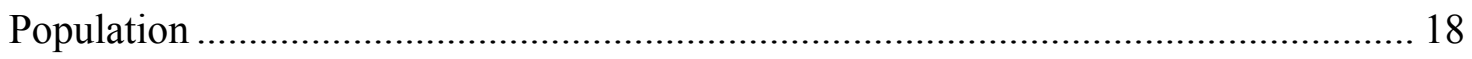

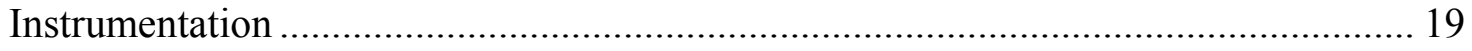

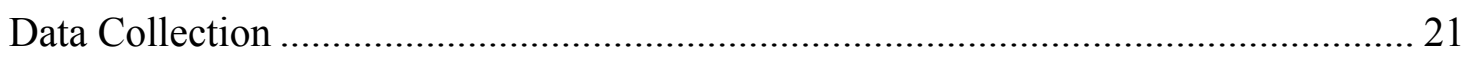




\section{CHAPTER IV}

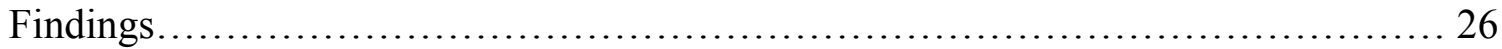

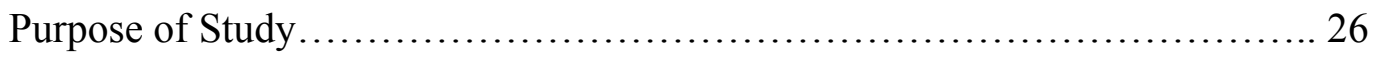

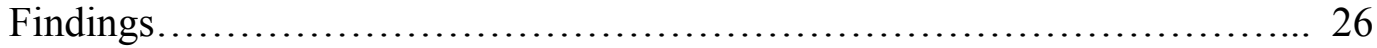

\section{CHAPTER V}

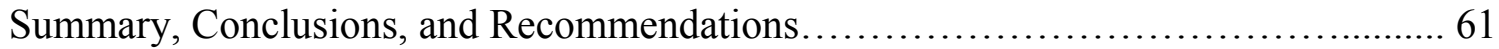

Purpose and Objectives of the Study ......................................61

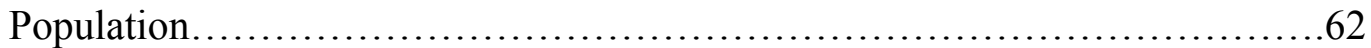

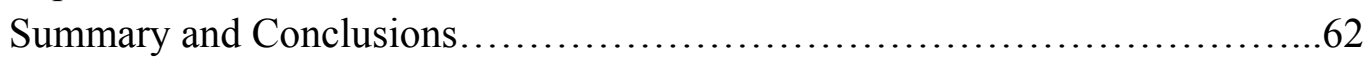

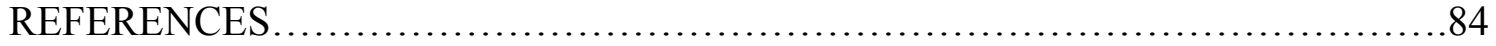

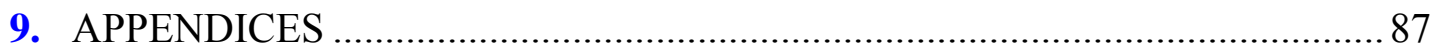




\section{LIST OF TABLES}

10. Reliability of Instruments

11. Comparison of Early and Late Respondents on Selected Variables

12. Comparison of Early and Late Respondents on Selected Variables - Part 2 _.....24

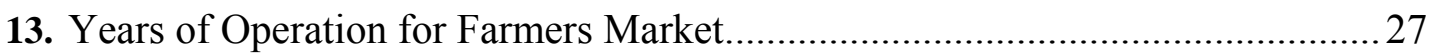

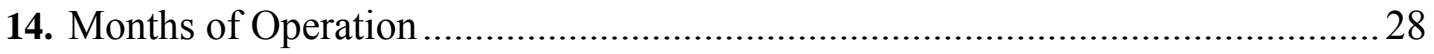

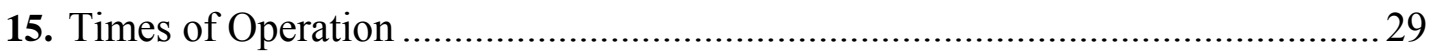

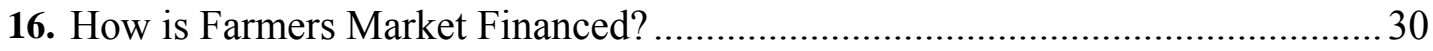

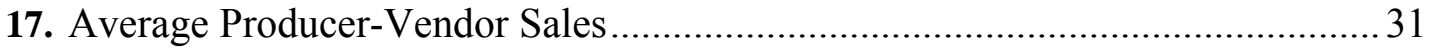

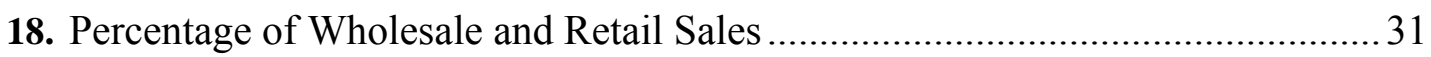

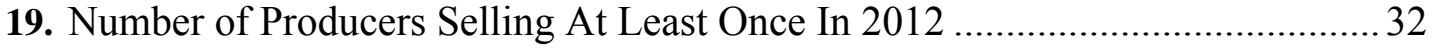

20. Products Sold At Farmers Markets In 2012........................................................ 33

21. Labels Used on Products Sold At Farmers Markets .............................................. 34

22. Market Restrictions on Products Sold.................................................................... 35

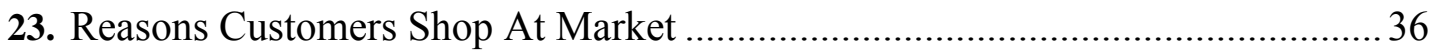

24. Permanent Location for Market …………………................................................. 37

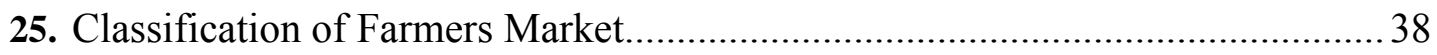

26. Effectiveness of Various Advertising Methods Used In Farmers Markets ..........39

27. Operating Budget and Advertising Expenditures In 2012 ..................................40 
28. Managers Conduct Periodic Customer Surveys?

29. Work Status of Market Manager. 42

30. Number of Employees Employed By Farmers Market.

31. Mangers' Perceptions of Operational Issues Needing Improvement 44

32. Areas of Assistance Needed To Increase Market Sales 47

33. Statement Most True for Your Market 48

34. Nutrition Programs and Credit/Debit Cards Used By Farmers Markets

35. Farmers Markets Participation In and Sales From WICFMNP, SFMNP, and EBT 50

36. Duties of Market Managers 52

37. Does Farmers Market Utilize A Written Job Description?.... 52

38. Written Documents Utilized By Farmers Markets 53

39. Gender of Market Managers 54

40. Age of Farmers Market Managers . 55

41. Years of Experience for Farmers Market Managers... 56

42. Farmers Market Manager's Educational Degree Level 57

43. Pay for Farmers Market Managers 58

44. Level of Farmers Market Manager Authority and Degree Assisting With New Market Locations 59

45. Sources of Information Used for Advice With Farmers Markets 60 
46. Chi-Square Analysis - Farmers Market Management Structure By Market

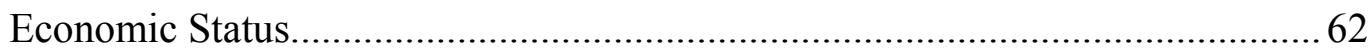

47. Chi-Square Analysis - Paid Market Manager and Market Status 63

48. Comparison of The Mean Scores of Paid Market Manager With Size of Farmers Market. 64

49. Comparison of The Mean Scores of Paid Market Manager With Age of Farmers Market. 66

50. Summary Data: Discriminant Analysis of Discriminating Variables 67

51. Classification of Cases Based on Discriminant Analysis and Years of Operation. .68 


\section{LIST OF FIGURES}

Figure 1 Copy of Stephens et al. 2006 Farmers Market Model.................................... 


\section{CHAPTER I}

\section{Introduction}

Farmers markets were a part of the culture in Europe and early settlers to the United States had a working knowledge passed onto them by their ancestors. An early article on farmers markets was written by Jane Pyle (1971), a geographer, who wrote for Geographical Review. The article titled "Farmers Markets in the United States: Functional Anachronisms?" showed the number of farmers markets were recorded in 1880, 1918, 1946, and continued through 1969. Markets were scattered across the country but were mainly in the eastern half of the United States around major population areas. Pyle (1971), contemporary economists, and geographers predicted the demise of farmers markets due to the rapid technological and infrastructure improvements that were occurring in the United States.

In a USDA report, Wann, Cake, Elliott and Burdette (1948) defined farmers markets as "places where farmers congregate to sell their own product." In the time period that followed definitions were offered for public market, municipal market, terminal market, farm shop, farm stands, roadside markets, tailgate market, and flea market. All the various definitions lead to several different interpretations of a farmers market. House Resolution 2458 provided that a farmers market is "any marketplace where at least ten farmers congregate for the purpose of selling their agricultural commodities directly to consumers in a manner designed to lower the cost of food for the consumers while providing an increased income to the farmers" (U.S. House of Representatives 1975, p. 4-5). 
Wann et al. (1948) looked at locations of farmers markets in the United States in 1946 and found the Northeast with 220, South with 328, Central with 152 and West with 24. The markets operating in 1946 were started after 1900 with a rapid growth around 1930.

In the decade following the publication of Pyle's article, there was a growth in farmers markets. This was contributed to the passage of Public Law 94-463 and the Farmer-to-Consumer Direct Marketing Act of 1976 which approved direct marketing as a legitimate activity of Cooperative Extension Services within the USDA. By allowing county agents to work with farmers and local activists to organize markets, there was a rapid growth in markets from 1977 through the 1980s.

Farmers markets have been a part of the food industry in the United States for almost as long as history (Webber, 2010). In the early 1900s, nearly 40 percent of Americans lived on farms, compared with 1 percent in 2000, and much of the food bought and consumed in the United States was grown locally (Pirog, 2009). Bachmann (2008) states farmers markets are an ancient method used across the world for selling produce directly to customers. There have been ups and downs in farmers markets with a decline after World War II followed by some reestablishment in the 1970s and 1980s (Webber, 2010). The most recent resurgence began in the 1990s and is still going today (Stephenson, Lev, \& Brewer, 2006). Speculation as to the driving forces behind this expansion was the use of farmers markets to build communities and this became a social life for the farmers and customers.

During the past twenty years developments have been made in local food systems with interest in local grown food. A growing interest in local foods in the United States 
is the result of various movements (Guptill \& Wilkins, 2002). Long distance transportation of food is considered by the environmental movement to contribute to greenhouse gas emissions. Other groups such as the community food-security and Slow Food movement have created awareness of safety, health, cultural food, and traditional ways of growing, producing and preparing food. The local food movement also reflects an increasing interest by consumers in supporting local farmers, and in better understanding the origin of their food (Ilbery \& Maye, 2005; Pirog, 2009).

Over several years farmers markets have obtained a recognizable percentage of the food industry. A USDA Agricultural Marketing Service report showed an 18.32 percent increase in operating markets from 1994 to 2006 (Bachmann, 2008). Stephenson et al. (2006) reported that for the past ten years farmers markets have been growing nationally.

Several of the markets have established a record of economic success. Markets such as the Pike Place Market in Seattle, Washington and the Soulard Market in St. Louis, Missouri are well established markets that have survived over the years (Webber, 2010). Many markets get started, but the ones which survive have had economic success as they matured. Markets that did not become self-sustainable were supported by cities, local government agencies, and nonprofit organizations or grants.

Farmers markets across the country vary greatly in their size and management structure by geographic regions as well as within states. When examining the operations of the markets, Ragland and Tropp (2006) found that having a market manager followed closely by vendor operated board of directors directs the farmers market. Oberholtzer and Grow (2003) in a survey of the Mid-Atlantic Region found that the key ingredient 
was the market manager. Jolly (2005) states the success of any market, and the financial success of the vendors, depends a great deal on the manager of the market. The life span of new markets is that half will close within a year (Stephenson et al., 2006). Being able

to have enough administrative revenue to provide sustainable management (manager) is a struggle for markets. This is a challenge to markets of all sizes, but seems to have a larger impact on the small scale markets.

\section{Problem}

With farmers markets increasing in popularity and numbers, a need exists to determine why some markets thrive while others fail. This researcher is defining a market as economically successful when the market's income is sufficient to pay for all costs associated with the operating of the market. A review of literature yielded some regional information however no information specific to West Virginia has been found. The problem being addressed is whether the market management structure of farmers markets is a contributing factor in the markets economic success.

\section{Purpose}

The purpose of this study is reflected in the following research questions:

1) Is there an association between the farmers' market management structure (manager, board of directors, or volunteers) and the economic success of West Virginia farmers markets?

2) Is there an association between the volunteer/paid status of the manager and the markets economic success? 
3) Is there an association between the size of the farmers' market and the volunteer/paid status of the manager?

4) Is there an association between the age of the farmers' market and the volunteer/paid status of the manager?

The information gained as a result of this study will provide a foundation for recommendations regarding farmers' market organization and planning that may enhance the success and longevity of individual farmers' markets. In addition this information will be utilized in educational materials to benefit farmers' market managers, board of directors, and others who assist with current management and strategic planning for farmers' markets.

\section{Hypotheses}

To answer the purpose of this research study the following hypotheses will be tested:

$\mathrm{H}_{\mathrm{o}}=$ Farmers' market management structure has no effect on market economic success. $\mathrm{H}_{\mathrm{A}}=$ Farmers' market management structure has an effect on market economic success.

$\mathrm{H}_{0}=$ Paid manager for farmers' market has no effect on market economic success. $\mathrm{H}_{\mathrm{A}}=$ Paid manager for farmers' market has an effect on market economic success.

$\mathrm{H}_{\mathrm{o}}=$ Size of the farmers' market has no effect on whether the manager is volunteer or paid. 
$\mathrm{H}_{\mathrm{A}}=$ Size of the farmers' market has an effect on whether the manager is volunteer or paid.

$\mathrm{H}_{\mathrm{o}}=$ Age of the farmers' market has no effect on whether the manager is volunteer or paid.

$\mathrm{H}_{\mathrm{A}}=$ Age of the farmers' market has an effect on whether the manager is volunteer or paid.

\section{Limitations}

The study was limited to farmers markets operating in West Virginia during the 2012 calendar year. 


\section{CHAPTER II}

\section{Review of Literature}

After reviewing the history of the farmers' markets one could visualize three areas under which farmers markets could be examined. These three areas are economic/social, environmental, and management structure/model. In the economic/social area there are returns and costs to the producers and the customers' wants and perceptions from a farmers market. The environmental area covers use of resources (renewable and nonrenewable), transportation, processing, greenhouse gas emissions, and storage. Management structure/model area deals with how the markets are managed and what type of management is seen in successful markets.

In one of the more recent books to be published concerning the current increase in farmers markets, the author explored the growing interest of consumers in wanting locally grown food. Stephenson (2008) investigated this movement and all the various components that are involved in a farmers market. In looking at the success or failure of farmers markets, management ecology is one of the areas that were examined.

Stephenson et al. (2006) examined successful farmers markets in the Northwest and synthesized a model that illustrated how farmers market organizers successfully adapted to barriers and challenges in their environment. One aspect identified was the area of Managing to Maximize Atmosphere, Products, and Community. The synthesized farmers market model and description were:

Market managers identified atmosphere, product, and community as key elements of good farmers markets. These elements may be seen as a target or goals for market organizers. Markets operate under wide-ranging 
external influences. Skilled management supports successful markets as they adapt to these influences, flourish, and reach market goals (Stephenson et al., 2006).

The synthesized model in Stephenson et al. (2006) places farmers markets in an environment made up of natural and political influences ranging from the dependence of crop production on local agro-ecozone conditions to the impacts of state and federal regulations (see Figure 1). Markets adapt to these conditions through management (represented by the blue band) and their adaptations are visible: they create an atmosphere conducive to socializing and sales, they procure a variety of high quality products, and they build community support via a loyal customer base and integration into local social and economic systems.

"Much of the ability to excel in the key traits of successful farmers markets is based on the use of management tools. Individual farmers markets have access to varying quantities of resources in terms of people, time and revenue. The availability of these resources impacts the ability of market organizers to manage and therefore, impacts the level and quality of management markets receive." (Stephenson et al., 2006, p. 7) 


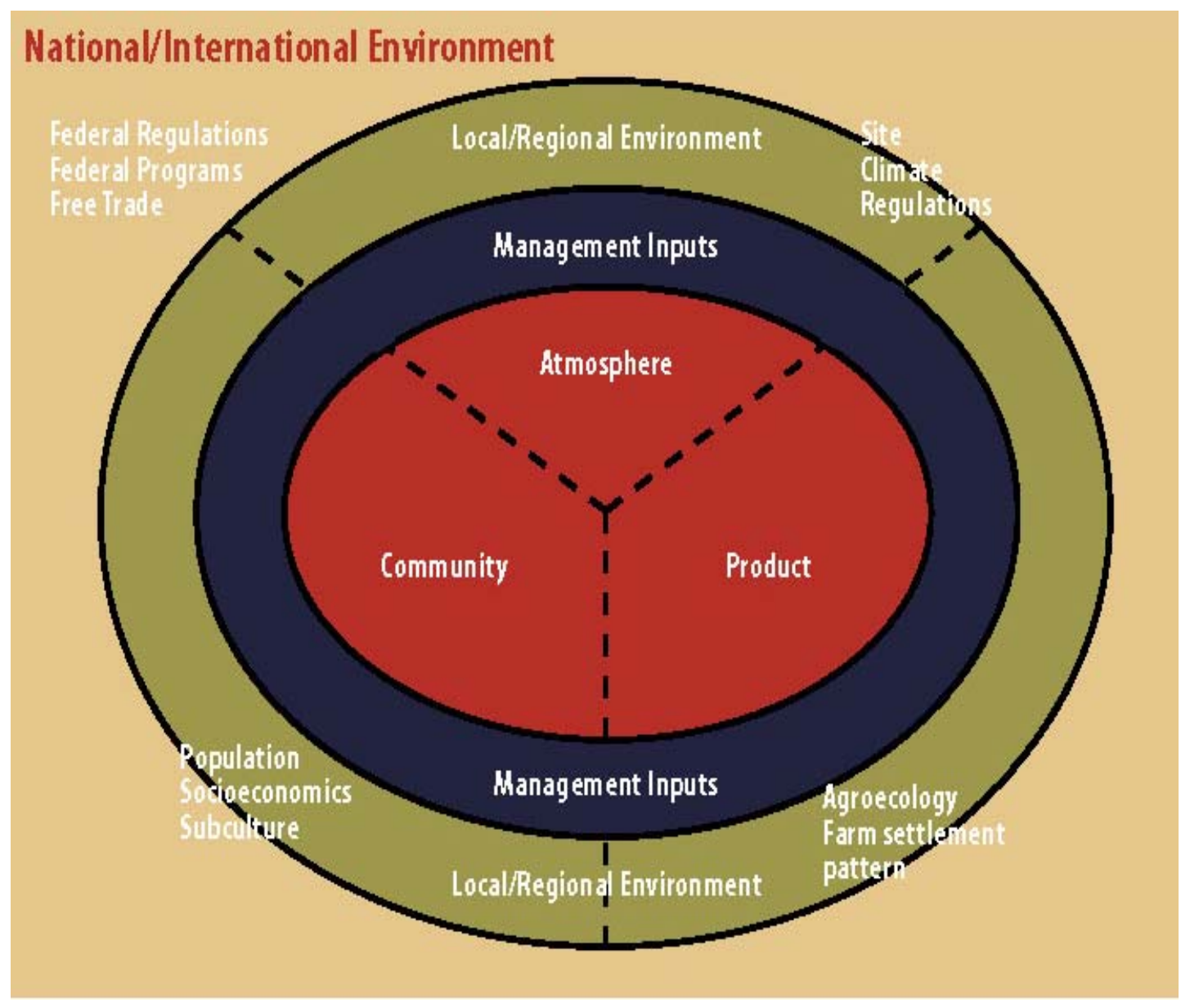

Figure 1. Stephenson et al. 2006 Farmers Market Model

Govindasamy, Italia, and Adelaja (2002) did a study on Farmers Markets:

Consumer Trends, Preferences, and Characteristics. Their summary and conclusions:

Knowledge of consumers preferences and expectations allow growers to plan production, pricing, and marketing strategies more efficiently. The identification of potential target markets based on socioeconomic and demographics characteristics could also aid managers and organizers of farmers markets when searching for strategic locations to set up these outlets (p. 6). 
Here the researchers are making the case that market managers are the focal point in managing farmers markets. They do not just oversee daily operations, but have to be knowledgeable of their customers' desires and relate this information to the growers, and are a resource in locating new potential locations for markets. A different perception of the manager's role is seen from the consumers' perspective. The manager is relied on to provide knowledge and advice to the growers that will assist them in meeting the customers' wants. In selecting market locations, the manager is expected to assist with providing information on socioeconomic data in establishing successful markets.

\section{Sales and Paid Management}

The National Farmers Market Manager Survey 2006 (Ragland \& Tropp, 2006) looked into several areas involving farmers markets, and the area of operational issues at farmers markets gave some insight into the markets that are successfully functioning. When asking who makes the rules in the farmers market, $36.6 \%$ indicated market manger followed closely by $32 \%$ indicating vendor operated board of directors. Of the markets that were becoming self-sufficient, $46.5 \%$, the largest percentage of these markets depended on vendor's fees to pay their operating expenses. The survey found that many

of the markets relied on voluntary labor and management. Paid market managers were in $39 \%$ of the markets and $22 \%$ of the markets hired paid employees outside of the manager. In looking at the difference in average sales, "markets with paid managers reported average sales of $\$ 56,375$ per month" while the markets with unpaid managers "reported average sales of \$11,059” (Ragland \& Tropp, 2006, p.58). The conclusion that resulted 
from the survey was that a direct relationship existed between the annual sales level of markets and likelihood that a paid manager was retained.

According to the USDA Agricultural Marketing Services 2006 National Farmers Market Survey, the most popular product category sold at farmers markets was fresh fruits and vegetables, which was sold by nearly 92 percent of farmers markets in 2005, followed by herbs and flowers, and honey, nuts, and preserves (Ragland and Tropp, 2009). However, not all products sold at farmers markets are part of the local food system (Hughes et al., 2007). For example, some vendors may come from outside the local region, and some local vendors may not sell products that are produced within the region.

\section{Market size and management}

Stephenson, Lev, \& Brewer (2007) examined the link between farmers market size and management organization to improve the management of the market as a way to improve market sustainability. By having market organization and a manager, they found that market rules were at the core of a well-managed market. In examining market size, the micro and small markets added management as they grew while medium and large markets added management complexity at their level. As the markets progressed in their years and size, management structure came into being and by-laws became more common. A large market without any management structure or organization would be chaos. 


\section{Market Manager}

Mainville (2010) reported six key issues as the foundation for building a successful market. Market manager is listed as one of these issues. The manager is the person that interacts with the vendors, customers, board members and general public. This individual needs to have several areas of strength and management ability to deal with the various responsibilities of a market manager.

In the survey conducted on producer only markets in a ten county area of Pennsylvania, Maryland and Washington, D.C. they found that "the market manager is a key ingredient in the success of a farmers market" (Oberholtzer \& Grow, 2003, p.13). Here a large percentage of the market managers were volunteers and only a small percent were employed. Another finding was the larger suburban areas had managers with farming experience while urban and rural areas did not. Within the Mid-Atlantic region, markets in Maryland were most likely to have managers with experience in farming.

Jolly (2005) stated the market manager could be working with a board of directors, volunteers, friends, community members, local government offices, and farmers. Delegation is an important tool for a market manager and the market can benefit from skillful use of delegation. Good delegations will allow sharing the work appropriately, judiciously, and effectively.

Govindasamy et al. (1998) found that market managers were employed by different sources and worked normally when the markets were open. Farmers felt that the managers did not understand what farming actually entailed since they did not visit the farms. Average age of the managers was 45 and the majority was Caucasian, graduated from college, and had an annual household income of $\$ 70,000.00$. Market 
location was in suburban areas close to urban areas. Factors determining location such as closeness to downtown, parking, visibility, accessibility and traffic flow, spacing for stands, and number of potential customers were reported. The markets have the potential for greater profit margins than other marketing outlets. Obstacles that still remain are attracting farmers to these markets, support from municipalities where the markets are located, and drawing customers to downtown area.

Zimet, Hewitt, \& Henry (1986) looked at vegetable farmers retail markets characteristics as to why they have not been successful. Producers' volume of production was found to be too low for the non-retail marketing channels. Volume that was found would be suited for direct sales outlets such as farmers markets. Few markets have been successful because they were lacking organization, which is a vital element for success. The market which was well organized and managed was successful. Management of the market is the responsibility of the producers/farmers that use it.

\section{Summary}

Farmers markets have been with us since ancient times as a way of selling produce to local consumers. These markets in the beginning were the main source of exchange between the farmers and consuming public. As new technologies of refrigeration, processing, transporting, grocery stores, etc., came about after the World Wars, farmers markets became of less importance. There was concern that the farmers markets would totally disappear from society. In the mid-1900s with questions concerning food safety, environmental impact of greenhouse gases emission, and health, 
interest from the public about these issues and where their food was produced brought back an interest in local food markets.

Farmers markets are becoming more numerous according to USDA data from the Economic Research Service, National Agricultural Statistics Service, and Census of Agriculture data. Data from the USDA National Agricultural Statistics Service shows total agricultural sales, direct-to-consumer sales and total at home consumption have all increased from 1997 to 2007. Even though this is a small percentage of the direct agriculture market and consumption, it does demonstrate the potential for possible growth.

Some work has been done in exploring how the consumers view farmers markets, purchasing characteristics of consumers, strategies for a successful market, sales value from farms, direct-to-consumer sales, numbers of farms producing, and products being sold at the markets. Most of this work has been done on a regional basis from a broad aspect and more detailed data is needed to get a better picture of the local food movement.

Sustainability of farmers markets from the perspective of management, or as Stephenson (2008) states "management ecology," needs to be examined in greater detail to see how all of the various factors interact with management. As was shown in the Farmers Market Model much of the success is based on the use of management tools. More research into exactly what is the tools that management employs and how they are employed could provide insight on how the sustainable markets have succeeded. 
Farmers markets are growing and are likely to continue to become a larger percentage of the food industry. Farmers markets remain viable and grow once established due to one vital element, organization and management. Several supporting characteristics/factors are present that contribute to the market success. As seen in the review of literature, all the authors' state in one form or another, the management organization and manager are the overriding factor that contributes to the success of the farmers markets. 


\section{CHAPTER III}

\section{Methodology}

\section{Purpose}

The purpose of this study is reflected in the following research questions:

1) Is there an association between the farmers market management structure (manager, board of directors, or volunteers) and the economic success of West Virginia farmers markets?

2) Is there an association between the volunteer/paid status of the manager and the markets economic success?

3) Is there an association between the size of the farmers market and the volunteer/paid status of the manager?

4) Is there an association between the age of the farmers market and the volunteer/paid status of the manager?

The information gained as a result of this study will provide a foundation for recommendations regarding farmers market organization and planning that may enhance the success and longevity of individual farmers markets. In addition this information will be utilized in educational materials to benefit farmers market managers, board of directors, and others who assist with current management and strategic planning for farmers markets. 


\section{Hypotheses}

To answer the purpose of this research study the following hypotheses will be tested:

$\mathrm{H}_{0}=$ Farmers market management structure has no effect on market economic success.

$\mathrm{H}_{\mathrm{A}}=$ Farmers' market management structure has an effect on market economic success.

$\mathrm{H}_{\mathrm{o}}=$ Paid manager for farmers' market has no effect on market economic success.

$\mathrm{H}_{\mathrm{A}}=$ Paid manager for farmers' market has an effect on market economic success.

$\mathrm{H}_{\mathrm{o}}=$ Size of the farmers' market has no effect on whether the manager is volunteer or paid.

$\mathrm{H}_{\mathrm{A}}=$ Size of the farmers' market has an effect on whether the manager is volunteer or paid.

$\mathrm{H}_{\mathrm{o}}=$ Age of the farmers' market has no effect on whether the manager is volunteer or paid.

$\mathrm{H}_{\mathrm{A}}=$ Age of the farmers' market has an effect on whether the manager is volunteer or paid.

\section{Research Design}

The research design that was used in examining the farmers markets as to their economic profitability according to their management style was descriptive correlational research. This research involved comparison of the management styles in the market and the effect it has on economic profitability. Ary, Jacobs and Sorensen (2010) stated 
"correlational research assesses the relationships among two or more variables in a single group" (p. 349). "Correlational research is useful in a wide variety of studies. The most useful applications of correlation are: (1) assessing relationships, (2) assessing consistency, and (3) prediction" (Ary, Jacobs and Sorensen, 2010, p. 351).

\section{Population}

The target population for this research study was the managers of farmers markets in the state of West Virginia. Due to the small number of known farmers markets operating in the state (80-100), the survey was sent to all of the markets making the target population the accessible population. Market information was obtained by contacting the West Virginia Department of Agriculture, National Resource Conservation Service, West Virginia Famers Market Association and WVU Small Farms Center. All farmers markets that were operated in communities and were not a commercially owned and operated business were included in the population.

By including all the farmers markets in the survey, sampling error was not a concern. In assembling the lists from the various sources and doing physical comparisons of the names to avoid duplications, we were able to address frame and selection errors. Measurement error was addressed by having the validity and reliability of the survey instrument established. This will be discussed in more detail later in this section. 


\section{Instrumentation}

A survey instrument from the National Farmers Market Manager Survey 2006 (Ragland \& Tropp, 2009) was used in developing the survey instrument for this research. The survey instrument began with a cover which had the title of the study along with some graphics and names of who was conducting the study. The instrument was divided into four parts examining distinct functions of a farmers market. Part I, Market Operations related to the type of market operations including months of operation, annual revenue, types of market customers, products sold, labeling of products, why customers buy at the market, and market restrictions. Part II, Market Management, asked questions dealing with market management in relation to type of facility, defining your market, advertising, customer surveys, sustainability of the market, fees assessed to vendors, paid or unpaid management, full or part-time manager, does the market employ workers, who develops rules for the market, and areas where improvement in the market is needed. Part III, Producer/Vendor Information, requested information pertaining to participants in the market, nutrition programs, EBT (Electronic Benefits Transfer), credit cards. Part IV, Market Manager, dealt with manager duties, does the market have a formal written structure, demographics on the manager, salary range paid, and authority given to the manager.

\section{Validity}

The instrument was provided to a panel of experts to determine its validity. This panel was comprised of faculty involved with research and/or teaching at West Virginia University Davis College of Agriculture, Natural Resources and Design and Extension 
Service. The experts made determinations as to the degree to which the instrument assessed the relevant aspects of the conceptual domain and "appeared" to measure what it purports to measure. Upon reviewing the instrument the panel concluded it had face and content validity.

\section{Reliability}

The instrument was piloted using a group of seven individuals consisting of market manager outside of WV and WVU Extension Agents that were knowledgeable of farmers markets. Since all of the markets in WV were included in the research, managers from these markets could not be used in the pilot. The Extension agents work in close relationship with the markets therefore they are knowledgeable of the market operations and how they function. These individuals provided feedback as to whether the questions were clearly understood, problems with the question wording, time it took to fill out the questionnaire, and were the instructions clear and understood.

Reliability of the instrument assessment for correlational research could be done by using test-retest, parallel forms, split-half, or co-efficient alpha (Ary, Jacobs and Sorensen, 2010, p.351). Spearman Brown split-half formula was used to analyze the pilot instrument data (Robinson, Shaver, \& Wrightsman, 1991). The areas of market operation, labels, restrictions and advertising were used in the analysis to determine the reliability of the instrument.

The questions that were examined for establishing reliability were: market operations (questions 2, 3, 6, and 7), market labels (question 9), market restrictions (question 10), and market advertising (question 14). Two of the constructs had "exemplary" reliability and two had "moderate" reliability. The same questions were examined in the final results with two 
constructs having "moderate" and two constructs having "exemplary" reliability (see Table $1)$.

Table 1

Reliability of Instruments

\begin{tabular}{|c|c|c|c|c|}
\hline \multirow[b]{2}{*}{ Variable } & \multicolumn{2}{|c|}{ Pilot Test } & \multicolumn{2}{|c|}{ Final Data Set } \\
\hline & $\begin{array}{c}\text { Spearman Brown } \\
\text { Coefficient }\end{array}$ & $\begin{array}{l}\text { Level of } \\
\text { Reliability }\end{array}$ & $\begin{array}{l}\text { Spearman Brown } \\
\text { Coefficient }\end{array}$ & $\begin{array}{l}\text { Level of } \\
\text { Reliability }^{1}\end{array}$ \\
\hline $\begin{array}{c}\text { Market } \\
\text { Operations }\end{array}$ & 0.475 & Exemplary & 0.134 & Moderate \\
\hline $\begin{array}{l}\text { Market } \\
\text { Labels }\end{array}$ & 0.14 & Moderate & 0.675 & Exemplary \\
\hline $\begin{array}{c}\text { Market } \\
\text { Restrictions }\end{array}$ & 0.618 & Exemplary & 0.363 & Exemplary \\
\hline $\begin{array}{c}\text { Market } \\
\text { Advertising }\end{array}$ & 0.134 & Moderate & 0.192 & Moderate \\
\hline
\end{tabular}

${ }^{1}$ Robinson, Shaver, \& Wrightsman, 1991

Exemplary $=\geq .30$, Extensive $=.20-.29$, Moderate $=.10-.19$, Minimal $=$ Below .10

\section{Data Collection}

Data collection procedures followed recommended by Dillman, Smyth, \& Christian (2009). First mailing of the survey packets was done on April 12, 2013. Included in the first mailing of the survey packet was the cover letter, self-administered questionnaire and stamped self-addressed envelope. Once the first mailing deadline had passed for respondents to have returned the survey, the first follow-up notice was mailed May 3, 2013 to those who had not returned the survey. 
A second mailing of the survey packet was mailed on May 15, 2013 to those that had not responded to the first follow-up deadline notice. Once the second mailing deadline had passed for respondents to have returned the survey, the second follow-up notice was mailed on June 6, 2013 to those who had not returned the survey. The researcher made personal contact by e-mail and phone to several of the markets that had not returned their surveys instruments. In several cases the wrong individual had received the survey packet and the researcher was provided the correct contact. Another mailing was sent to the new contact containing the survey packet information asking them to complete the survey.

A total of 90 survey packets were mailed on the initial mailing based on the data base that had been compiled from various agencies. It was determined by returns and email responses that seven of the markets had closed or ceased to operate in 2012 . We received two new markets that were not on any data base. This gave a total population of 85 farmers markets with a response from 56 markets for 65.88 percent rate of return.

\section{Non-Response Error}

To address non-response error, a comparison of early respondents to late respondents was made (Dillman, Smyth, and Christians, 2009). Late respondents are similar to non-respondents so the responses from the early mailings were compared to the respondents from the late mailings by running a comparison on a selection of variables. If no important differences are found between the early and late respondents, one can assume the respondents are an unbiased sample of the recipients and one can generalize to the total group. 
In doing the analysis for questions five and seven a t-test was used and for questions three, 13, and 40 a Pearson Chi-Square test was used. Question 13 was recoded to compare the beginning, struggling, and getting started farmers markets as "struggling/beginning" and sustaining and successful farmers markets as "successful." Out of the five questions tested the written job description was statistical significant ( $\alpha \leq$ $.05)$ (see Tables 2 and 3). Because early and late respondents were different, we limited generalization to the 52 respondents.

Table 2

Comparison of Early and Late Respondents on selected Variables

\begin{tabular}{cccccccc}
\hline Examined Areas & Late & $\mathrm{N}$ & $\mathrm{M}$ & $\mathrm{SD}$ & $\mathrm{t}$ & $\mathrm{df}$ & $\mathrm{Sig}$ \\
\hline Total Sales & No & 33 & $\$ 54,762.94$ & $\$ 113,843.93$ & 0.704 & 40 & 0.486 \\
Producer/vendor & Yes & 9 & $\$ 27,566.00$ & $\$ 31,071.21$ & & & \\
Number of & No & 41 & 31 & 74.591 & 0.736 & 51 & 0.465 \\
Producers & Yes & 12 & 15 & 9.733 & & & \\
\hline
\end{tabular}

\section{Data Analysis}

Information from the questionnaire was collected and entered into the SPSS program for windows. The alpha level of significance was set $a$ priori at $\alpha \leq .05$ for all statistical tests. Descriptive analyses appropriate for the respective scales of measurement were performed on the data including measures of central tendency (mean, median, or mode) and variability (frequencies or standard deviation). The results were represented 
as frequencies and percentages as well as mean, median and mode in both table and narrative form.

Table 3

Comparison of Early and Late Respondents on selected Variables - Part 2

\begin{tabular}{|c|c|c|c|c|c|}
\hline Examined Areas & Code & Late & $\mathrm{N}$ & Chi Value & Sig. \\
\hline \multirow[t]{4}{*}{ Time of Operation } & One day & No & 25 & 1.659 & 0.198 \\
\hline & & Yes & 11 & & \\
\hline & Two day & No & 17 & & \\
\hline & & Yes & 3 & & \\
\hline \multirow[t]{4}{*}{ Market Status } & Group 1 & No & 16 & 1.222 & 0.269 \\
\hline & & Yes & 3 & & \\
\hline & Group 2 & No & 24 & & \\
\hline & & Yes & 10 & & \\
\hline \multirow{4}{*}{$\begin{array}{l}\text { Written job } \\
\text { description }\end{array}$} & Yes & No & 7 & 6.386 & $0.012^{*}$ \\
\hline & & Yes & 7 & & \\
\hline & No & No & 32 & & \\
\hline & & Yes & 6 & & \\
\hline
\end{tabular}

$* \alpha \leq .05$

Following are the statistical procedures used for answering the research questions:

1. Chi-square statistical procedure was performed to determine if an association existed between farmers' market management structure (manager, board of directors, or volunteers) and the economic success of West Virginia farmers markets. 
2. Chi-square statistical procedure was performed to determine if an association existed between the volunteer/paid status of a manager and the markets success.

3. An independent t-test statistical analysis was used to determine if there existed a relationship between the size of the farmers' market and the volunteer/paid status of the manager.

4. An independent t-test statistical analysis was used to determine if a relationship existed between the age of the farmers' market and the volunteer/paid status of the manager.

\section{Use of Findings}

The results of this study will provide a foundation for recommendations regarding farmers' market organization and planning that may enhance the success and longevity of individual farmers' markets. In addition this information will be utilized in educational materials to benefit farmers' market managers, board of directors, and others who assist with current management and strategic planning for farmers markets.

Extension Service, WV Farmers Market Association, and other community development professionals will utilize the findings to assist with the development of new and existing farmers markets in the state. 


\section{CHAPTER IV}

\section{Findings}

\section{Purpose of the Study}

The purpose of this study is reflected in the following research questions:

1) Is there an association between the farmers' market management structure (manager, board of directors, or volunteers) and the economic success of West Virginia farmers markets?

2) Is there an association between the volunteer/paid status of the manager and the markets economic success?

3) Is there an association between the size of the farmers' market and the volunteer/paid status of the manager?

4) Is there an association between the age of the farmers' market and the volunteer/paid status of the manager?

\section{Findings}

Question \#1: Including 2012, how many years has your market been in operation?

The years of operation for the 56 farmers markets ranged from one year to 30 years of operation. The markets had been in operation an average of 9.46 years with a standard deviation of 8.43 (see Table 4). 
Table 4

Years of Operation for Farmers Market

\begin{tabular}{ccccc}
\hline & M & SD & Min & Max \\
\hline Years of Operation & 9.46 & 8.43 & 1 & 30 \\
\hline
\end{tabular}

Question \#2: What months are your markets open?

May through October would be considered the main operating months for farmers markets. Over 50 markets were open during this time period. All of the farmers markets were open in the months of July and August. Fifty-five markets (98\%) were open in September. At the beginning of the summer season there were 30 markets $(54 \%)$ operating in May and 47 markets (84\%) operating in June. There were 45 markets (80\%) operating in October. During the traditional winter months there are a small number of markets operating (see Table 5). 
Table 5

Months of Operation

\begin{tabular}{lcc}
\hline & & Yes \\
\cline { 2 - 3 } & $\mathrm{N}$ & $\%$ \\
\hline January & 5 & 9 \\
February & 6 & 11 \\
March & 7 & 13 \\
April & 14 & 25 \\
May & 30 & 54 \\
June & 47 & 84 \\
July & 56 & 100 \\
August & 56 & 100 \\
September & 55 & 98 \\
October & 45 & 80 \\
November & 9 & 16 \\
December & 7 & 13 \\
\hline
\end{tabular}

Question \#3: What are your times of operation?

The majority of the markets reported operating one day a week $(\mathrm{N}=36,64.3 \%)$.

Twenty markets operated two days per week $(\mathrm{N}=20,35.7 \%)$ (see Table 6). 
Table 6

Times of Operation

\begin{tabular}{lcc}
\hline & N & $\%$ \\
\hline Weekly - one day each week & 36 & 64.3 \\
Two days a week & 20 & 35.7 \\
Once a month & 0 & 0 \\
Twice a month & 0 & 0 \\
\hline
\end{tabular}

Question \#4: How did your market finance its operation in 2012?

Respondents were asked to indicate how the market financed its operations. Thirty-four respondents indicated they used producer-vendor fees as a financial source. They reported that 69.21 percent of their finances $(\mathrm{SD}=35.69)$ came from producer vendor fees. Eighteen respondents reported "other" as a financial source for their market. Of the 18 respondents, an average of 72.56 percent of the finances $(\mathrm{SD}=33.91)$ came from these "other" sources. Financial sources listed in the other category were: sale plus commission, received outside funding, grant funding, donations and fundraisers, local sponsors paying bills, use of fairgrounds at no charge, and manager finances.

The remaining farmers markets were being financed by farmers markets association $(\mathrm{N}=6)$, trade or business association $(\mathrm{N}=2)$, city-county municipal government agency $(\mathrm{N}=8)$, state government agency $(\mathrm{N}=6)$, and non-profit organization $(\mathrm{N}=7)$ (see Table 7). The percent of financing from these sources varied from 46.0 to 69.0 percent and included: farmers' markets association $(\mathrm{M}=69.0 \%, \mathrm{SD}=$ 36.41), trade or business association ( $\mathrm{M}=57.0 \%, \mathrm{SD}=60.81)$, city-county municipal 
government agency $(M=49.63, S D=33.3)$, state government agency $(M=49.0, S D=$ 38.44), and non-profit organization ( $\mathrm{M}=46.0, \mathrm{SD}=39.79)$.

\section{Table 7}

How is Farmers Market Financed?

\begin{tabular}{lccccc}
\hline & N & M & SD & Min & Max \\
\hline Producer-vendor fees & 34 & 69.21 & 35.69 & 2 & 100 \\
State government agency & 6 & 49.00 & 38.44 & 10 & 100 \\
$\begin{array}{l}\text { City-county municipal government } \\
\text { agency }\end{array}$ & 8 & 49.63 & 33.30 & 5 & 100 \\
Non-profit organization & 7 & 46.00 & 39.79 & 5 & 100 \\
Farmers market association & 6 & 69.00 & 36.41 & 14 & 100 \\
$\begin{array}{l}\text { Trade or business association (e.g., } \\
\text { Chamber of Commerce) }\end{array}$ & 2 & 57.00 & 60.81 & 14 & 100 \\
Other & 18 & 72.56 & 33.91 & 2 & 100 \\
\hline
\end{tabular}

Question \#5: What were the total producer/vendor sales at your market in 2012?

Respondents were asked to report the total producer/vendor sales for 2012. The farmers markets reported sales ranging from a minimum of $\$ 500.00$ to maximum of $\$ 450,000.00$. The mean sales were $\$ 48,935.02$ with a standard deviation of $102,134.29$ (see Table 8). Twenty-five percent of the farmers markets did not report any sales data. 
Table 8

Average Producer-Vendor Sales

\begin{tabular}{cccccc}
\hline & $\mathrm{N}$ & $\mathrm{M}$ & $\mathrm{SD}$ & $\mathrm{Min}$ & $\mathrm{Max}$ \\
\hline Total Producer-Vendor Sales & 56 & 48935.02 & 102134.29 & $\$ 500$ & $\$ 450,000$ \\
\hline
\end{tabular}

Question \#6: On average in 2012, what percentages of market sales were generated by the following types of market patrons?

Respondents were asked to indicate the percentage of retail and wholesale sales. Fifty-one markets reported retail sales. Of the 51 markets, retail sales were reported as 98.18 percent $(\mathrm{SD}=4.31)$ of their total sales. Eleven of the markets indicated their market had a wholesale component. Of the 11 markets wholesales sales accounted for an average of 7.55 percent $(\mathrm{SD}=6.49)$ of their total sales (see Table 9).

Table 9

Percentage of Wholesale and Retail Sales

\begin{tabular}{lccccc}
\hline & N & M & SD & Min & Max \\
\hline \% Retail Sales & 51 & 98.18 & 4.31 & 75 & 100 \\
\% Wholesale Sales & 11 & 7.55 & 6.49 & 2 & 25 \\
\hline
\end{tabular}

Question \#7: How many producers/vendors sold at least once at your market in 2012?

Respondents were asked to report the number of vendors selling at their market. The number of producers reported selling at the farmers' markets ranged from one to 479 different producer/vendors. The mean was 27.38 vendors $(\mathrm{SD}=65.92)$ (see Table 10$)$. 
Table 10

Number of Producers Selling at Least Once in 2012

\begin{tabular}{cccccc}
\hline & N & M & SD & Min & Max \\
\hline Number of Producers (2012) & 56 & 27.38 & 65.92 & 1 & 479 \\
\hline
\end{tabular}

Question \#8: Please indicate the number of producers/vendors, who sold products at your market in 2012?

Respondents were asked to indicate the number of vendors selling specific categories of products. Fifty-four markets reported selling "fresh fruits and vegetables" with a mean of 11.93 vendors and standard deviation of 15.68 . This was followed by 48 markets selling honey, nuts, jams, and jellies and preserves $(\mathrm{M}=3.66$ vendors, $\mathrm{SD}=$ 3.4); 47 markets selling baked goods $(\mathrm{M}=3.51$ vendors, $\mathrm{SD}=3.14)$; 45 markets offering herbs, flowers, and plants for sale $(\mathrm{M}=3.98$ vendors, $\mathrm{SD}=4.82)$; 40 markets with meat, eggs, and/or poultry products for sale $(\mathrm{M}=2.69$ vendors, $\mathrm{SD}=3.45)$; and 31 markets selling crafts-woodworking items $(\mathrm{M}=3.27$ vendors, $\mathrm{SD}=7.05)$ to make the top six products. The number of markets with other products included : 10 markets with "other" products $(\mathrm{M}=2.88$ vendors, $\mathrm{SD}=4.9) ; 17$ markets with prepared food items $(\mathrm{M}=1.12$ vendors, $\mathrm{SD}=1.92) ; 11$ markets with other processed foods $(\mathrm{M}=.76$ vendors, $\mathrm{SD}=$ $1.85) ; 10$ markets with milk, and/or dairy products $(\mathrm{M}=.49$ vendors, $\mathrm{SD}=1.33)$; and seven markets with fish and/or seafood products $(\mathrm{M}=.24$ vendors, $\mathrm{SD}=.69)$ (see Table 11). 
Table 11

Products Sold at Farmers’ Markets in 2012

\begin{tabular}{|c|c|c|c|c|c|}
\hline & $\mathrm{N}$ & M & SD & Min & Max \\
\hline Fresh fruits and vegetables & 54 & 11.93 & 15.68 & 1 & 107 \\
\hline Milk and-or dairy products & 10 & 0.49 & 1.33 & 0 & 8 \\
\hline $\begin{array}{l}\text { Meat, eggs, and-or poultry } \\
\text { products }\end{array}$ & 40 & 2.69 & 3.45 & 0 & 15 \\
\hline Fish and-or seafood & 7 & 0.24 & 0.69 & 0 & 4 \\
\hline Herbs, flowers, and plants & 45 & 3.98 & 4.82 & 0 & 25 \\
\hline $\begin{array}{l}\text { Honey, nuts, jams, jellies, and } \\
\text { preserves }\end{array}$ & 48 & 3.66 & 3.4 & 0 & 16 \\
\hline Baked goods & 47 & 3.51 & 3.14 & 0 & 17 \\
\hline $\begin{array}{l}\text { Prepared food (for immediate } \\
\text { consumption) }\end{array}$ & 17 & 1.12 & 1.92 & 0 & 8 \\
\hline Other processed foods & 11 & 0.76 & 1.85 & 0 & 10 \\
\hline Crafts-woodworking & 31 & 3.27 & 7.05 & 0 & 40 \\
\hline Other & 10 & 2.88 & 4.9 & 0 & 15 \\
\hline
\end{tabular}

Question \#9: What labels are used by producers/vendors to sell products?

The respondents were asked to indicate the types of labels used in their market. Producers/vendors predominately label their products as "locally grown" based on analysis of the data. Locally grown was reported from 49 of the markets (90.7\%). Other labels included 22 markets (40.7\%) using "pasture-raised-free range-cage free," 21 markets (38.9\%) reporting the use of "chemical-free-pesticide-free," and 13 markets (24.1\%) using "hormone-free-antibiotic-free" labeling. "Certified USDA Organic" $(\mathrm{N}=$ 
2) and "Certified Naturally Grown" $(\mathrm{N}=4)$ both were reported being used by less than 10 percent of the markets (see Table 12).

Table 12

Labels Used on Products Sold at Farmers’ Markets

\begin{tabular}{lcccc}
\hline & \multicolumn{2}{c}{ Yes } & \multicolumn{2}{c}{ No } \\
\cline { 2 - 5 } & $\mathrm{N}$ & $\%$ & $\mathrm{~N}$ & $\%$ \\
\hline Locally grown & 49 & 90.7 & 5 & 9.3 \\
Certified USDA Organic & 2 & 3.7 & 52 & 96.3 \\
Certified Naturally Grown & 4 & 7.4 & 50 & 92.6 \\
Pasture-raised-free range-cage free & 22 & 40.7 & 32 & 59.3 \\
Chemical-free-pesticide-free & 21 & 38.9 & 33 & 61.1 \\
Hormone-free-antibiotic-free & 13 & 24.1 & 41 & 75.9 \\
Other & 9 & 17.3 & 43 & 82.7 \\
\hline
\end{tabular}

Question \#10: The following statements address market restrictions.

Respondents were asked about restrictions on products offered at their markets. Thirty-two markets $(60.4 \%)$ of the agricultural producers are only allowed to sell farm products they "produce themselves." Restrictions on producers being allowed to "resell other local farm products" were the second most reported item $(\mathrm{N}=28,53.8 \%)$. The third most popular restriction used by markets was the "range of items is limited" that can be sold $(\mathrm{N}=27,50.9 \%)$. Products that were considered "selling outside local area" were limited by 24 markets (46.2\%). "Product mix" being sold by a producer/vendor was used as a limiting factor in five markets (9.3\%) (see Table 13$)$. 
Table 13

Market Restrictions on Products Sold

\begin{tabular}{lcccc}
\hline & \multicolumn{2}{c}{ Yes } & \multicolumn{3}{c}{ No } \\
\cline { 2 - 5 } & $\mathrm{N}$ & $\%$ & $\mathrm{~N}$ & $\%$ \\
\hline Produce themselves & 32 & 60.4 & 21 & 39.6 \\
Resell other local products & 28 & 53.8 & 24 & 46.2 \\
Sell outside local area & 24 & 46.2 & 28 & 53.8 \\
Range of items is limited & 27 & 50.9 & 26 & 49.1 \\
$\begin{array}{l}\text { Product mix controlled by } \\
\text { limiting vendors }\end{array}$ & 5 & 9.3 & 49 & 90.7 \\
\hline
\end{tabular}

Question \#11: Please rank the top three reasons why you believe customers shopped at your market in 2012.

Of the 56 markets surveyed, 44 markets $(78.6 \%)$ reported customers shopped at their market because of "freshness and condition of product." The second most popular reason customers shopped at their market was "access to locally produced food" $(\mathrm{N}=32$, 57.1\%). The third most popular reason customers shopped was "support of local agriculture" $(\mathrm{N}=30,53.6 \%)$. Other reasons that were indicated were: "price" $(\mathrm{N}=18$, $32.1 \%)$; "taste and texture of product" $(\mathrm{N}=12,21.4 \%)$; "variety of products offered" (N $=11,19.6 \%)$; "ability to know how food products are produced" $(\mathrm{N}=7,12.5 \%)$ and other" $(\mathrm{N}=7,12.5 \%)$ (see Table 14$)$. 
Table 14

Reasons Customers Shop at Market

\begin{tabular}{|c|c|c|c|c|c|c|c|c|}
\hline & \multicolumn{2}{|c|}{ First } & \multicolumn{2}{|c|}{ Second } & \multicolumn{2}{|c|}{ Third } & \multicolumn{2}{|c|}{ Total } \\
\hline & $\mathrm{N}$ & $\%$ & $\mathrm{~N}$ & $\%$ & $\mathrm{~N}$ & $\%$ & $\mathrm{~N}$ & $\%$ \\
\hline Price & 6 & 33.3 & 6 & 33.3 & 6 & 33.3 & 18 & 32.1 \\
\hline $\begin{array}{l}\text { Freshness and } \\
\text { condition of } \\
\text { product }\end{array}$ & 19 & 43.2 & 17 & 38.6 & 8 & 18.2 & 44 & 78.6 \\
\hline $\begin{array}{l}\text { Taste and texture } \\
\text { of product }\end{array}$ & 2 & 16.7 & 5 & 41.7 & 5 & 41.7 & 12 & 21.4 \\
\hline $\begin{array}{l}\text { Support of local } \\
\text { agriculture }\end{array}$ & 8 & 26.7 & 13 & 43.3 & 9 & 30 & 30 & 53.6 \\
\hline $\begin{array}{l}\text { Variety of } \\
\text { products offered }\end{array}$ & 1 & 9.1 & 6 & 54.5 & 4 & 36.4 & 11 & 19.6 \\
\hline $\begin{array}{l}\text { Access to locally } \\
\text { produced food }\end{array}$ & 16 & 50 & 7 & 21.9 & 9 & 28.1 & 32 & 57.1 \\
\hline $\begin{array}{l}\text { Ability to know } \\
\text { how food } \\
\text { products are } \\
\text { produced }\end{array}$ & 0 & 0 & 0 & 0 & 7 & 100.0 & 7 & 12.5 \\
\hline Other & 3 & 42.9 & 0 & 0 & 4 & 57.1 & 7 & 12.5 \\
\hline
\end{tabular}

Question \#12: Does your market operate in a permanent location?

The market managers were asked if they had a permanent market location. Fiftyone respondents $(91.1 \%)$ indicated they had a permanent location (see Table 15$)$. 
Table 15

Permanent Location for Market

\begin{tabular}{lcccc}
\hline & \multicolumn{3}{c}{ Yes } & \multicolumn{2}{c}{ No } \\
\cline { 2 - 5 } & $\mathrm{N}$ & $\%$ & $\mathrm{~N}$ & $\%$ \\
\hline Permanent location & 51 & 91.1 & 5 & 8.9 \\
\hline
\end{tabular}

Question \#13: How do you define your market?

Given the option of beginning, struggling, getting started, sustaining, or successful, market managers were asked to describe their market. Twenty farmers market managers $(37.7 \%)$ defined their individual market as "successful" (five plus years operation, covering cost of operation and extra funds). Fourteen managers $(26.4 \%)$ classified their market as "sustaining" (third to fifth year of operation and covering cost). Successful and sustaining accounted for 34 (64.1\%) of the 56 markets surveyed. Six markets were just "getting started" (11.3\%) (first to third year of operation) and four markets (7.5\%) were "beginning" (2012 was first year of operation). Nine markets considering themselves as "struggling" $(17.0 \%)$ (more than one year of operation but not covering cost of operation) (see Table 16). 
Table 16

Classification of Farmers Market

\begin{tabular}{lcc}
\hline & $\mathrm{N}$ & $\%$ \\
\hline Beginning & 4 & 7.5 \\
Struggling & 9 & 17.0 \\
Getting started & 6 & 11.3 \\
Sustaining & 14 & 26.4 \\
Successful & 20 & 37.7 \\
\hline
\end{tabular}

Question \#14: Please rate each of the following methods of advertising that your market currently uses. (1-Not effective-5-Very effective-6-NA)

Market managers were asked to rate the effectiveness of a series of advertising methods. Twenty managers (37\%) listed signs-banners on market day or during season as very effective for advertising. This was followed closely by social media being ranked as very effective in 16 markets $(32.7 \%)$. The next four methods of advertising ranked very effective were: newspaper $(\mathrm{N}=13,26.5 \%)$, brochures-flyers $(\mathrm{N}=9,18 \%)$, newsletter $(\mathrm{N}$ $=8,15.7 \%)$, and website $(\mathrm{N}=8,15.4 \%)$. The other areas farmers' markets indicated they used were: radio $(6.3 \%)$, direct mail $(6.1 \%)$, and television $(6 \%)$. The "other" category was listed by 6 markets $(7.7 \%)$ with the following advertising areas highlighted: participation in other community events; word of mouth; co-market sale; mail out post cards at opening; recycled bags; and advertising at other farmers' markets in the area (see Table 17). 
Table 17

Effectiveness of Various Advertising Methods Used in Farmers' Markets

\begin{tabular}{|c|c|c|c|c|c|c|c|c|c|c|c|c|}
\hline & \multicolumn{2}{|c|}{$\begin{array}{c}\text { Not } \\
\text { effective }\end{array}$} & \multicolumn{2}{|r|}{2} & \multicolumn{2}{|c|}{3} & \multicolumn{2}{|c|}{4} & \multicolumn{2}{|c|}{$\begin{array}{c}\text { Very } \\
\text { effective }\end{array}$} & \multicolumn{2}{|c|}{$\begin{array}{l}\text { Not } \\
\text { Used }\end{array}$} \\
\hline & $\mathrm{N}$ & $\%$ & $\mathrm{~N}$ & $\%$ & $\mathrm{~N}$ & $\%$ & $\mathrm{~N}$ & $\%$ & $\mathrm{~N}$ & $\%$ & $\mathrm{~N}$ & $\%$ \\
\hline Newspaper & 1 & 2 & 4 & 8.2 & 13 & 26.5 & 15 & 30.6 & 13 & 26.5 & 3 & 6.1 \\
\hline Radio & 2 & 4.2 & 0 & 0 & 7 & 14.6 & 7 & 14.6 & 3 & 6.3 & 29 & 60.4 \\
\hline Television & 1 & 2 & 1 & 2 & 3 & 6 & 2 & 4 & 3 & 6 & 40 & 80 \\
\hline $\begin{array}{l}\text { Brochures- } \\
\text { flyers }\end{array}$ & 1 & 2 & 2 & 4 & 13 & 26 & 13 & 26 & 9 & 18 & 12 & 24 \\
\hline Direct mail & 1 & 2 & 1 & 2 & 2 & 4.1 & 4 & 8.2 & 3 & 6.1 & 38 & 77.6 \\
\hline Newsletter & 0 & 0 & 3 & 5.9 & 7 & 13.7 & 4 & 7.8 & 8 & 15.7 & 29 & 56.9 \\
\hline $\begin{array}{l}\text { Signs-banne } \\
\text { on market da } \\
\text { or during } \\
\text { season }\end{array}$ & 0 & 0 & 2 & 3.7 & 8 & 14.8 & 19 & 35.2 & 20 & 37 & 5 & 9.3 \\
\hline Website & 2 & 3.8 & 3 & 5.8 & 8 & 15.4 & 6 & 11.5 & 8 & 15.4 & 25 & 48.1 \\
\hline $\begin{array}{l}\text { Social media } \\
\text { (Facebook, } \\
\text { Twitter) }\end{array}$ & 1 & 2 & 5 & 10.2 & 6 & 12.2 & 7 & 14.3 & 16 & 32.7 & 14 & 28.6 \\
\hline Other & 2 & 15.4 & 0 & 0 & 2 & 15.4 & 2 & 15.4 & 1 & 7.7 & 6 & 46.2 \\
\hline
\end{tabular}

Question \#15 \& \#16: What was your market's annual operating budget in 2012? How much did your market spend on advertising in 2012?

Market managers were asked to provide information on their operating budget and advertising expenses for 2012. In 2012 farmers markets had an average operating budget of $\$ 2,015.86(\mathrm{SD}=3452.75)$. The markets spent an average of $\$ 740.37(\mathrm{SD}=$ 1934.87) for advertising the markets. The maximum amount spent on budgets was 
$\$ 15,000.00$ and maximum funds expended on advertising were $\$ 12,000.00$ (see Table 18).

Table 18

Operating Budget and Advertising Expenditures in 2012

\begin{tabular}{lccccc}
\hline & $\mathrm{N}$ & $\mathrm{M}$ & $\mathrm{SD}$ & $\mathrm{Min}$ & $\mathrm{Max}$ \\
\hline Annual budget & 34 & 2015.86 & 3452.75 & $\$ 0$ & $\$ 15,000$ \\
Advertising budget & 29 & 740.37 & 1934.87 & $\$ 0$ & $\$ 12,000$ \\
\hline
\end{tabular}

Question \#17: Does your market conduct periodic customer surveys to assess customer preferences?

Respondents were asked if they conducted customer surveys. Of the 52 markets that reported, $24(46.2 \%)$ indicated they conducted periodic customer surveys to assess customer preferences and $28(53.8 \%)$ markets did not conduct periodic customer surveys (see Table 19).

Table 19

Managers Conduct Periodic Customer Surveys?

\begin{tabular}{lcccc}
\hline & \multicolumn{3}{c}{ Yes } & \multicolumn{2}{c}{ No } \\
\cline { 2 - 5 } & $\mathrm{N}$ & $\%$ & $\mathrm{~N}$ & $\%$ \\
\hline Customer surveys & 24 & 46.2 & 28 & 53.8 \\
\hline
\end{tabular}


Question \#18: What types of fees are producers/vendors charged to sell at your market?

The respondents were asked to select from a list of several different types of fees that farmers markets use. No fee was charged by 18 of the 56 markets (32.1\%). Flat fee charges (21.4\%) including the following: \$5/market; \$20/market; \$25/market; $\$ 20 /$ season; $\$ 40 /$ season and $\$ 50 /$ season. Two markets (3.6\%) charged a percentage of the sales ( $1.5 \%$ and $20 \%$ donation). Farm inspection fees were not charged by any of the markets. A membership fee was charged by 26.8 percent of the markets ( $\$ 5 /$ set-up, $\$ 25 /$ year to $\$ 50 /$ year). Space fees $(14.3 \%)$ at the markets covered the following range: $\$ 5 /$ day; $\$ 2$ or $\$ 10 /$ week; $\$ 50 /$ space; and $\$ 25$ or $\$ 100 /$ season. Other fees $(10.7 \%)$ ranged from a low of $\$ 2 /$ one time to $\$ 10 /$ day, but also listed $\$ 50$ escrow account and "nonprofits are free."

Question \#19: Please indicate the work status of your market manager.

Market managers were asked to indicate their work status. Out of the 46 markets that reported the work status of their market manager, 24 (52.2\%) said their manager was part time seasonal (works only when market is open). Ten respondents $(21.7 \%)$ indicated their manager worked part time year round. Eight markets (17.4\%) had a full time year round manager. Four markets (8.7\%) had full time seasonal manager (see Table 20). 
Table 20

Work Status of Market Manager

\begin{tabular}{lcc}
\hline & $\mathrm{N}$ & $\%$ \\
\hline $\begin{array}{l}\text { Part-time seasonal -works only when market is open } \\
\begin{array}{l}\text { Part-time year-round -works when market is open and when } \\
\text { board requests }\end{array}\end{array}$ & 10 & 21.7 \\
$\begin{array}{l}\text { Full-time seasonal -works only during market season } \\
\text { Full-time year-round -works all year }\end{array}$ & 4 & 8.7 \\
\hline
\end{tabular}

Question \#20, \#21, \#22, \#23, \& \#24: Including your market manager, how many fulltime seasonal workers, full time year-around, part-time seasonal, part-time year around, and volunteers does your market employ?

Respondents were asked to indicate the status of workers employed by the market. Full time seasonal workers were employed in 10 markets with an average of .33 workers $(\mathrm{SD}=.9)$ and a maximum number of five employees. Part time seasonal workers were employed in 10 markets with an average of .25 employees $(\mathrm{SD}=.59)$ and a maximum of three workers. Year round workers were employed in five markets. There were an average of .14 workers $(\mathrm{SD}=.49)$ and a maximum of three year round workers in any one location. Part time year round workers were employed in five markets with an average of $.12(\mathrm{SD}=.38)$ and a maximum of two workers employed. Thirty-three markets used volunteers with a mean of 2.6 workers $(\mathrm{SD}=3.52)$. The maximum number of volunteers in one market was 15 (see Table 21). 
Table 21

Number of Employees Employed by Farmers' Market

\begin{tabular}{lccccc}
\hline & N & M & SD & Min & Max \\
\hline Full time seasonal & 10 & 0.33 & 0.9 & 0 & 5 \\
Year-round & 5 & 0.14 & 0.49 & 0 & 3 \\
Part-time seasonal & 10 & 0.25 & 0.59 & 0 & 3 \\
Part-time year-round & 5 & 0.12 & 0.38 & 0 & 2 \\
Volunteers & 33 & 2.6 & 3.52 & 0 & 15 \\
\hline
\end{tabular}

Question \#25: Please rank the top three operational issues that need improvement in your market?

Respondents were asked to rank the top three operational issues they faced in their market. Combining the first, second, and third choices, the top three operational issues where improvement was needed included: 1$)$ customer numbers $(\mathrm{N}=28,50.0 \%)$; 2) advertising-publicity $(\mathrm{N}=25,44.6 \%)$; and 3$)$ low sales per producer/vendor $(\mathrm{N}=20$, $35.7 \%)$. Next three areas were: other $(\mathrm{N}=15,26.8 \%)$, development of business plans for the market $(\mathrm{N}=14,25.0 \%)$, and access to public restrooms $(\mathrm{N}=13,23.2 \%)$. The remaining areas were as follows: liability insurance coverage and certified processingkitchen facilities $(\mathrm{N}=11,19.6 \%)$; parking for customers and utilities $(\mathrm{N}=4,7.1 \%)$; waste management $(\mathrm{N}=2,3.6 \%)$; and tenant agreements/relationship with market tenants $(\mathrm{N}=1,1.8 \%)($ see Table 22$)$.

The "other" category contained the following comments: fundraising for expansion; development of management board and fees to pay manager; ability to take food stamps; more vendors to have a variety of products offered; due to significant 
increase in volume due to high tunnel production-- space for expansion is necessary; vendor count/participation; more space for market; everybody sells out normally; vendor number; 1 . more producers 2 . more variety of produce; vendor recruitment; number of vendors; market coordinator; and vendors! No farmers want to drive down into [city].

Table 22

Mangers’ Perceptions of Operational Issues Needing Improvement

\begin{tabular}{|c|c|c|c|c|c|c|c|c|}
\hline & \multicolumn{2}{|c|}{ First } & \multicolumn{2}{|c|}{ Second } & \multicolumn{2}{|c|}{ Third } & \multicolumn{2}{|c|}{ Total } \\
\hline & $\mathrm{N}$ & $\%$ & $\mathrm{~N}$ & $\%$ & $\mathrm{~N}$ & $\%$ & $\mathrm{~N}$ & $\%$ \\
\hline $\begin{array}{l}\text { Customer number (low } \\
\text { attendance) }\end{array}$ & 22 & 78.6 & 4 & 14.3 & 2 & 7.1 & 28 & 50.0 \\
\hline $\begin{array}{l}\text { Low sales per producer- } \\
\text { vendor }\end{array}$ & 3 & 15.0 & 13 & 65.0 & 4 & 20.0 & 20 & 35.7 \\
\hline $\begin{array}{l}\text { Development of business } \\
\text { plan for market }\end{array}$ & 2 & 14.3 & 4 & 28.6 & 8 & 57.1 & 14 & 25.0 \\
\hline Advertising-publicity & 9 & 36.0 & 9 & 36.0 & 7 & 28 & 25.0 & 44.6 \\
\hline Liability insurance coverage & 2 & 18.2 & 4 & 36.4 & 5 & 45.5 & 11 & 19.6 \\
\hline $\begin{array}{l}\text { Tenant } \\
\text { agreements/relationships } \\
\text { with market tenants }\end{array}$ & 0 & 0 & 1 & 100 & 0 & 0 & 1 & 1.8 \\
\hline Parking for customers & 0 & 0 & 2 & 50.0 & 2 & 50.0 & 4 & 7.1 \\
\hline Access to public restrooms & 4 & 30.8 & 5 & 38.5 & 4 & 30.8 & 13 & 23.2 \\
\hline $\begin{array}{l}\text { Utilities (e.g., electricity, } \\
\text { water) }\end{array}$ & 1 & 25.0 & 2 & 50.0 & 1 & 25.0 & 4 & 7.1 \\
\hline $\begin{array}{l}\text { Certified processing-kitchen } \\
\text { facilities }\end{array}$ & 1 & 9.1 & 4 & 36.4 & 6 & 54.5 & 11 & 19.6 \\
\hline Waste management & 0 & 0 & 0 & 0 & 2 & 100 & 2 & 3.6 \\
\hline Other & 11 & 73.3 & 0 & 0 & 4 & 26.7 & 15 & 26.8 \\
\hline
\end{tabular}


Question \#26: Who develops rules, regulations, and producer/vendor criteria for your market?

Market managers were asked who developed rules, regulations, and producer/vendor criteria for your market. Twenty-seven out of the 56 markets (49.1\%) have governing rules, regulation, and producer criteria made by "members of the market association." The second most popular response was that governance was determined by the "market manager" $(\mathrm{N}=19,34.5 \%)$. Seventeen markets (30.9\%) had "producervendor-operated Board of Directors." Other methods of governance included: other ( $\mathrm{N}=$ $13,24.1 \%)$; state government agency $(\mathrm{N}=12,21.8 \%)$; city-county or municipal government agency $(\mathrm{N}=10,18.2 \%)$; and community association-non-profit organization $(\mathrm{N}=5,9.1 \%),($ see Table 23).

Table 23

Who Makes Rules, Regulations, and Producer Criteria?

\begin{tabular}{lcc}
\hline & \multicolumn{2}{c}{ Yes } \\
\cline { 2 - 3 } & 12 & 21.8 \\
\hline State government agency & 10 & 18.2 \\
City-county or municipal government agency & 17 & 30.9 \\
Producer-vendor-operated Board of Directors & 5 & 9.1 \\
Community association-non-profit organization & 27 & 49.1 \\
Members of the market association & 19 & 34.5 \\
Market manager & 13 & 24.1 \\
Other & & \\
\hline
\end{tabular}


Question \#27: What types of market assistance do you believe would help your market's producers/vendors increase their sales?

Respondents were asked to indicate their first, second, and third choices for types of assistance they could use to help increase their sales. Combining their first, second, and third choices, thirty-seven (66.1\%) of the 56 markets said that "training on merchandising retail displays" was the number one assistance that would help increase producers/vendors sales. Other areas of assistance to increase market sales was "research on local customer demographics and preference" $(\mathrm{N}=31,55.4 \%)$, "training on business plan development" $(\mathrm{N}=22,39.3 \%)$, and "improvement in layout of facility" $(\mathrm{N}=14$, 5.0\%). Other selections made were: support-funding for local food promotion campaign and other $(\mathrm{N}=10,17.9 \%)$; support-funding for producer-vendor advertising and publicity $(\mathrm{N}=6,10.7 \%)$; renovation of aging facility $(\mathrm{N}=5,8.9 \%)$; and training on how to better target customers ( $\mathrm{N}=1,1.8 \%$ ), (see Table 24 ). 
Table 24

Areas of Assistance Needed to Increase Market Sales

\begin{tabular}{|c|c|c|c|c|c|c|c|c|}
\hline & \multicolumn{2}{|c|}{ First } & \multicolumn{2}{|c|}{ Second } & \multicolumn{2}{|c|}{ Third } & \multicolumn{2}{|c|}{ Total } \\
\hline & $\mathrm{N}$ & $\%$ & $\mathrm{~N}$ & $\%$ & $\mathrm{~N}$ & $\%$ & $\mathrm{~N}$ & $\%$ \\
\hline $\begin{array}{l}\text { Improvements in layout of } \\
\text { facility }\end{array}$ & 8 & 57.1 & 3 & 21.4 & 3 & 21.4 & 14 & 25.0 \\
\hline $\begin{array}{l}\text { Renovation of aging } \\
\text { facility }\end{array}$ & 3 & 60.0 & 0 & 0 & 2 & 40.0 & 5 & 8.9 \\
\hline $\begin{array}{l}\text { Training on how to better } \\
\text { target consumers }\end{array}$ & 0 & 0 & 1 & 100 & 0 & 0 & 1 & 1.8 \\
\hline $\begin{array}{l}\text { Training on business plan } \\
\text { development }\end{array}$ & 6 & 27.3 & 9 & 40.9 & 7 & 31.8 & 22 & 39.3 \\
\hline $\begin{array}{l}\text { Support-funding for } \\
\text { producer-vendor } \\
\text { advertising and publicity }\end{array}$ & 2 & 33.3 & 2 & 33.3 & 2 & 33.3 & 6 & 10.7 \\
\hline $\begin{array}{l}\text { Training on } \\
\text { merchandising retail } \\
\text { displays }\end{array}$ & 24 & 64.9 & 8 & 21.6 & 5 & 13.5 & 37 & 66.1 \\
\hline $\begin{array}{l}\text { Support-funding for local } \\
\text { food promotion } \\
\text { campaigns }\end{array}$ & 2 & 20.0 & 3 & 30 & 5 & 50.0 & 10 & 17.9 \\
\hline $\begin{array}{l}\text { Research on local } \\
\text { customer demographics } \\
\text { and preference }\end{array}$ & 5 & 16.1 & 17 & 54.8 & 9 & 29.0 & 31 & 55.4 \\
\hline Other & 6 & 60.0 & 1 & 10.0 & 3 & 30.0 & 10 & 17.9 \\
\hline
\end{tabular}

Question \#28: Which of the following statements about your market was MOST true in 2012?

Given a choice of three statements, respondents were asked to describe their market in 2012. The statement "we have more demand than supply" was reported by 23 markets (44.2\%). "Our supply and demand are roughly equal" was reported by 15 
respondents (28.8\%) and "we have more supply that demand" was indicted by 14 respondents $(26.9 \%)$ (see Table 25$)$.

Table 25

Statement Most True for Your Market

\begin{tabular}{lcc}
\hline & $\mathrm{N}$ & $\%$ \\
\hline We have more demand than supply & 23 & 44.2 \\
We have more supply than demand & 14 & 26.9 \\
Our supply and demand are roughly equal & 15 & 28.8 \\
\hline
\end{tabular}

Question \#29, \#32, \#35, \& \#38: Do producers/vendors at your market participate in Women, Infants, and Children (WIC) Farmers Market Nutrition Program, Senior Farmers Market Nutrition Program, or accept SNAP using Electronic Benefits Transfer (EBT) technology and credit/debit cards?

The farmers markets have the opportunity to participate in several USDA nutrition programs and electronic sales so they were asked to indicate which programs they participated in during the 2012 market year. Forty-eight of the markets $(87.3 \%)$ participated in Senior Farmers Market Nutrition program. Women, Infants, and Children (WIC) Farmers Market Nutrition Program was in 33 markets (61.1\%). SNAP using Electronic Benefits Transfer $(\mathrm{EBT})(\mathrm{N}=10,18.2 \%)$ and credit/debit card sales $(\mathrm{N}=7$, $13.5 \%$ ) were used in 10 or fewer markets (see Table 26). 
Table 26

Nutrition Programs and Credit/Debit Cards Used by Farmers’ Markets

\begin{tabular}{lcccc}
\hline & \multicolumn{2}{c}{ Yes } & \multicolumn{2}{c}{ No } \\
\cline { 2 - 5 } & $\mathrm{N}$ & $\%$ & $\mathrm{~N}$ & $\%$ \\
\hline $\begin{array}{l}\text { Women, Infants, and Children (WIC) } \\
\text { Farmers Market Nutrition Program }\end{array}$ & 33 & 61.1 & 21 & 38.9 \\
Senior Farmers Market Nutrition Program & 48 & 87.3 & 7 & 12.7 \\
$\begin{array}{l}\text { SNAP using Electronic Benefits Transfer } \\
\text { (EBT) }\end{array}$ & 10 & 18.2 & 45 & 81.8 \\
Credit-debit sales & 7 & 13.5 & 45 & 86.5 \\
\hline
\end{tabular}

Question \#30, \#31, \#33, \#34, \#36, \& \#37: How many producers/vendors at your market participated in the WIC Farmers Market Nutrition Program in 2012? What was the value of WIC Farmers Market Nutrition Program sales at your market in 2012? How many producers/vendor at your market participated in the Senior Farmers Market Nutrition Program in 2012? What was the value of Senior Farmers Market Nutrition Program sales at your market in 2012? How many producers/vendors at your market participated in EBT sales in 2012? What was the value of EBT sales at your market in 2012?

Respondents were asked about the participation in and sales from WICFMNP, SFMNP, and EBT programs. Forty-eight of the farmers markets participated in the Senior Farmers Market Nutrition Program (SFMNP) in 2012. The average market participation was $8.88(\mathrm{SD}=17.0)$ and a maximum of 117 participants in any one market. Twenty-three markets reported the value of the sales from SFMNP. The average sales was $\$ 1,193.78$ $(\mathrm{SD}=\$ 1,729.88)$ with sales ranging from a minimum sale of $\$ 30.00$ to a maximum of $\$ 7,000.00$. 
Thirty-one markets participated in the Women, Infant, and Children Farmers Market Nutrition Program (WICFMNP) with an average of 10.41 vendors $(\mathrm{SD}=20.67)$ and a maximum of 117 participants. Value of sales from WICFMNP was reported from 11 farmers markets with the maximum sale of $\$ 4,000.00$ and an average of $\$ 602.40$ (SD $=$ \$1215.92).

The least amount of participation was in Electronic Benefits Transfer (EBT) with nine farmers markets with a maximum of 117 participants and an average of 25.0 (32.91). Value of sales from EBT was reported from nine farmers markets with the maximum sale of $\$ 1,761.00$ and a mean of $\$ 524.93(\mathrm{SD}=650.24)$ (see Table 27).

Table 27

Farmers' Markets Participation In and Sales from WICFMNP, SFMNP, and EBT

\begin{tabular}{lccccc}
\hline & $\mathrm{N}$ & $\mathrm{M}$ & $\mathrm{SD}$ & Min & Max \\
\hline $\begin{array}{l}\text { Producers participate in WIC } \\
\begin{array}{l}\text { Farmers Market Nutrition } \\
\text { Program }\end{array}\end{array}$ & 31 & 10.41 & 20.67 & 0 & 117 \\
$\begin{array}{l}\text { Value of WICFMNP sales } \\
\text { Producers participate in }\end{array}$ & 11 & $\$ 602.40$ & $\$ 1215.92$ & $\$ 0$ & $\$ 4,000$ \\
$\begin{array}{l}\text { Senior Farmers Market } \\
\text { Nutrition Program }\end{array}$ & 48 & 8.88 & 17 & 1 & 117 \\
$\begin{array}{l}\text { Value SFMNP } \\
\text { Producers participating in }\end{array}$ & 23 & $\$ 1193.78$ & $\$ 1729.88$ & $\$ 30$ & $\$ 7,000$ \\
EBT & 9 & 25 & 32.91 & 0 & 117 \\
Value of EBT sales & 9 & $\$ 524.93$ & $\$ 650.24$ & $\$ 0$ & $\$ 1,761$ \\
\hline
\end{tabular}


Question \#39: What are the duties of the market manager?

Respondents were asked their perceptions of the duties of the market manager. Forty-four of the 56 markets (88.0\%) reported the top duty of the market manager was "settling disputes, handling problems." Other duties of the market manager included: opening and closing the market $(\mathrm{N}=39,78 \%)$, public relations spokesperson for the market $(\mathrm{N}=38,76.0 \%)$, advertising $(\mathrm{N}=35,70.0 \%)$, dealing with regulations $(\mathrm{N}=30$, $60.0 \%)$, assigning vendor spaces in the market $(\mathrm{N}=29,58.0 \%)$, and collecting data $(\mathrm{N}=$ $26,52.0 \%)$. Other areas selected covered keeping financial records $(\mathrm{N}=21,42.0 \%)$, managing websites $(\mathrm{N}=20,40.0 \%)$, newsletter $(\mathrm{N}=20,40.0 \%)$, social media along with promoting food safety $(\mathrm{N}=20,40.0 \%)$, writing grants $(\mathrm{N}=16,32.0 \%)$, farm inspections, $(\mathrm{N}=15,30.0 \%)$, operating EBT machine $(11=20,22.0 \%)$, and other $(\mathrm{N}=3,6.7 \%)$, (see Table 28).

Question \#40: Does the market manager have a written job description?

Of the 56 farmers' markets surveyed, 52 reported on the status of a written job description. Fourteen markets (26.9\%) reported they had a written job description and 38 markets (73.1\%) did not have a written job description (see Table 29). 
Table 28

Duties of Market Managers

\begin{tabular}{|c|c|c|}
\hline & \multicolumn{2}{|c|}{ Yes } \\
\hline & $\mathrm{N}$ & $\%$ \\
\hline Farm inspections & 15 & 30 \\
\hline Collecting data (e.g., customer counts, products sold) & 26 & 52 \\
\hline Operating EBT machine & 11 & 22 \\
\hline Public relations spokesperson for the market & 38 & 76 \\
\hline Settling disputes, handling problems & 44 & 88 \\
\hline Assigning vendor spaces in the market & 29 & 58 \\
\hline Opening and closing the market & 39 & 78 \\
\hline Advertising (e.g., designing, placing ads, writing, radio spots) & 35 & 70 \\
\hline Writing grants & 16 & 32 \\
\hline Keeping financial records & 21 & 42 \\
\hline $\begin{array}{l}\text { Dealing with regulations (e.g., health, agricultural, state, } \\
\text { county, city) }\end{array}$ & 30 & 60 \\
\hline Managing websites, newsletter, social media & 20 & 40 \\
\hline Promoting food safety & 20 & 40 \\
\hline Other & 3 & 6.7 \\
\hline
\end{tabular}

Table 29

Does Farmers’ Market Utilize a Written Job Description?

\begin{tabular}{lccccc}
\hline & \multicolumn{3}{c}{ Yes } & \multicolumn{2}{c}{ No } \\
\cline { 2 - 5 } & $\mathrm{N}$ & $\%$ & $\mathrm{~N}$ & $\%$ \\
\hline Written job description & 14 & 26.9 & 38 & 73.1 \\
\hline
\end{tabular}


Question \#41: Which of the following written documents does your market have?

Respondents were asked about specific written documents pertaining to market operations. Out of the 50 respondents, 44 farmers markets (88.0\%) had written market rules and six $(12.0 \%)$ markets did not have written market rules. Respondents with written By-Laws were divided evenly between yes and no with 25 markets (50.0\%) having written By-Laws and 25 markets (50.0\%) did not have the documents. Sixteen markets (32.0\%) had Product Lists and 34 (68.0\%) markets did not. Nine markets (18.0\%) had a Grievance Policy and 41 markets (82.0\%) did not. Three markets (6.0\%) had a Constitution and 47 (94.0\%) markets did not (see Table 30).

Table 30

Written Documents Utilized by Farmers' Markets

\begin{tabular}{lcccc}
\hline & \multicolumn{2}{c}{ Yes } & \multicolumn{2}{c}{ No } \\
\cline { 2 - 5 } & $\mathrm{N}$ & $\%$ & $\mathrm{~N}$ & $\%$ \\
\hline Constitution & 3 & 6.0 & 47 & 94.0 \\
By-Laws & 25 & 50.0 & 25 & 50.0 \\
Market Rules & 44 & 88.0 & 6 & 12.0 \\
Grievance Policy & 9 & 18.0 & 41 & 82.0 \\
Product List & 16 & 32.0 & 34 & 68.0 \\
\hline
\end{tabular}

Question \#42: What is the gender of your market manager?

Respondents were asked basic demographic questions including gender. In 26 markets $(52.0 \%)$ the manager was female and $20(40.0 \%)$ markets had male managers. 
Four $(8.0 \%)$ of the markets had multiple managers which mean they had both male and female managers working (see Table 31).

Table 31

Gender of Market Managers

\begin{tabular}{lcc}
\hline & $\mathrm{N}$ & $\%$ \\
\hline Male & 20 & 40.0 \\
Female & 26 & 52.0 \\
Multiple managers & 4 & 8.0 \\
\hline
\end{tabular}

Question \#43: What is the age of your market manager?

Given a series of age ranges, the market managers were asked their age. Fifty-five of the markets reported with 42 of the markets $(76.4 \%)$ indicating the age of the market manager was 41 years of age or older. The 51-60 age group $(\mathrm{N}=15)$ led the way with $27.3 \%$, followed by $41-50$ age group $(\mathrm{N}=14)$ at 25.5 percent and 60 and over age group (N 13) coming in at 23.6\%. Seven markets (12.7\%) were in the 31-40 age group and six markets $(10.9 \%)$ were in the $21-30$ age group. None of the markets reported having managers under 20 years of age (see Table 32). 
Table 32

Age of Farmers’ Market Managers

\begin{tabular}{lcc}
\hline & $\mathrm{N}$ & $\%$ \\
\hline Under 20 & 0 & 0.0 \\
$21-30$ & 6 & 10.9 \\
$31-40$ & 7 & 12.7 \\
$41-50$ & 14 & 25.5 \\
$51-60$ & 15 & 27.3 \\
60 and over & 13 & 23.6 \\
\hline
\end{tabular}

Research Questions \#44: How many years of market manager experience does your market manager have?

The managers were asked about the number of years of experience at the position. Out of the 49 total markets reporting, 23 markets (46.9\%) had managers with 1-5 years of experience. Twelve of the markets $(24.5 \%)$ had managers with 6-10 years of experience. Seven of the markets $(14.3 \%)$ had less than one year of experience. Five markets $(10.2 \%)$ had managers with over 25 years of experience. One market $(2 \%)$ had managers with 11-15 or 21-25 years of experience (see Table 33). 
Table 33

Years of Experience for Farmers’' Market Managers

\begin{tabular}{lcc}
\hline & $\mathrm{N}$ & $\%$ \\
\hline Less than one year & 7 & 14.3 \\
$1-5$ & 23 & 46.9 \\
$6-10$ & 12 & 24.5 \\
$11-15$ & 1 & 2.0 \\
$16-20$ & 0 & 0.0 \\
$21-25$ & 1 & 2.0 \\
Over 25 & 5 & 10.2 \\
\hline
\end{tabular}

Question \#45: Please indicate your market manager's highest degree.

The market managers were asked about their educational level. Bachelor's degree was reported by $20(38.5 \%)$ of the 52 markets reporting. A manager with a high school diploma or equivalent degree was in $16(30.8 \%)$ of the markets. An individual with a Master's degree was in $14(26.9 \%)$ of the markets. One market (1.9\%) had a manager with a Doctoral degree and one manager checked the other $(1.9 \%)$ category (see Table 34). 
Table 34

Farmers’ Market Manager's Educational Degree Level

\begin{tabular}{lcc}
\hline & $\mathrm{N}$ & $\%$ \\
\hline Less than a high school diploma & 0 & 0.0 \\
High school diploma or equivalent & 16 & 30.8 \\
Bachelor's degree & 20 & 38.5 \\
Master's degree & 14 & 26.9 \\
Doctoral degree & 1 & 1.9 \\
Other & 1 & 1.9 \\
\hline
\end{tabular}

Question \#46: Please indicate what your market pays to your manager.

Using one-thousand dollar increments, the managers were asked about their salary. For the 16 farmers markets that indicated they were paying a manager, five (31.3\%) paid less than $\$ 1,000.00$. Three markets $(18.8 \%)$ paid $\$ 1,001.00-\$ 2,000.00$ and three markets $(18.8 \%)$ paid over $\$ 10,000.00$ to their market managers. Two markets $(12.5 \%)$ paid in the $\$ 5,001.00$ - $\$ 10,000.00$ range. One market $(6.3 \%)$ paid in each of the other salary ranges (see Table 35 ). 
Table 35

Pay for Farmers’ Market Managers

\begin{tabular}{lll}
\hline & N & $\%$ \\
\hline Less than $\$ 1,000$ & 5 & 31.3 \\
$\$ 1,001$ to $\$ 2000$ & 3 & 18.8 \\
$\$ 2,001$ to $\$ 3,000$ & 1 & 6.3 \\
$\$ 3,001$ to $\$ 4,000$ & 1 & 6.3 \\
$\$ 4,001$ to $\$ 5,000$ & 1 & 6.3 \\
$\$ 5,001$ to $\$ 10,000$ & 2 & 12.5 \\
Over $\$ 10,000$ & 3 & 18.8 \\
\hline
\end{tabular}

Question \#47 \& 48: Does the market manager have the authority to enforce the market rules? Is the market manager involved in supplying the demographic, economic, and housing data on new market locations when selecting a new site?

Market managers were asked if they had the authority to enforce market rules. In 46 markets (93.9\%) market managers have the authority to enforce the rules of the market. When asked if the market manager assisted in getting demographic data on locations for consideration of a new market, 23 (52.3\%) markets said yes and $21(47.7 \%)$ markets said no (see Table 36). 
Table 36

Level of Farmers’ Market Manager Authority and Degree Assisting With New Market Locations

\begin{tabular}{lcccc}
\hline & \multicolumn{2}{c}{ Yes } & \multicolumn{2}{c}{ No } \\
\cline { 2 - 5 } & $\mathrm{N}$ & $\%$ & $\mathrm{~N}$ & $\%$ \\
\hline Market manager authority & 46 & 93.9 & 3 & 6.1 \\
Demographic data & 23 & 52.3 & 21 & 47.7 \\
\hline
\end{tabular}

Question \#49: Which of the following does the manager use to get information or advice?

The managers were asked about the sources of information they used on marketing issues. The local county extension agent was used by $45(88.2 \%)$ of the managers as a source of advice and information. WV Department of Agriculture had 33 (64.7\%) managers contacting them for advice and information. The local health department was a source of information and advice for 31 (60.8\%) managers. Twentyseven managers (52.9\%) contacted the WV Farmers Market Association while 49 percent $(\mathrm{N}=25)$ obtained information from the WV Small Farm Center. Local government agencies $(\mathrm{N}=20,39.2 \%)$ and local economic development organizations $(\mathrm{N}=13,25.5 \%)$ were the two other sources of information used by managers (see Table 37). 
Table 37

Sources of Information Used for Advice with Farmers Markets

\begin{tabular}{lcccc}
\hline & \multicolumn{2}{c}{ Yes } & \multicolumn{2}{c}{ No } \\
\cline { 2 - 5 } & $\mathrm{N}$ & $\%$ & 6 & 11.8 \\
\hline Local county extension agent & 45 & 88.2 & 26 & 51 \\
WV Small Farm Center & 25 & 49.0 & 24 & 47.1 \\
WV Farmers Market Association & 27 & 52.9 & & \\
Local economic development & & & 38 & 74.5 \\
organization & 13 & 25.5 & 20 & 39.2 \\
Health Department & 31 & 60.8 & 31 & 60.8 \\
Local government agencies & 20 & 39.2 & 18 & 35.3 \\
WV Department of Agriculture & 33 & 64.7 & & \\
\hline
\end{tabular}

\section{Question \#50: Comments}

The survey participants were provided a blank space to just list their comments. A complete set of comments is included in Appendix G.

\section{Hypothesis \#1}

For the purpose of the following analysis economic success was determined using respondents' indicators of their market economic status. The status categories of beginning, struggling, and getting started were recoded into one category (Struggling) and sustaining and successful were recoded into a second category (Successful). A chisquare test of independence was used to determine if there was a significant association between the variables state government agency, city-county or municipal government 
agency, producer-vendor board of directors, community association-non-profit organization, members of the market association, market manager and market status. The following hypotheses were tested:

$\mathrm{H}_{\mathrm{o}}=$ Farmers market management structure is independent of market economic status. $\mathrm{H}_{\mathrm{A}}=$ There is an association between farmers market management structure and market economic status.

The chi-square analysis $(\chi=.794, \mathrm{df}=1)$ determined there was not a significant difference between state government agency and market status. The chi-square analysis $(\chi=3.581, \mathrm{df}=1)$ determined there was not a significant difference between city-county or municipal government agency and market status. The chi-square analysis $(\chi=1.173$, $\mathrm{df}=1$ ) determined there was not a significant difference between producer-vendor board of directors and market status. The chi-square analysis of $(\chi=.377, \mathrm{df}=1)$ determined there was not a significant difference between community association-non-profit and market status. The chi-square analysis of $(\chi=1.768, \mathrm{df}=1)$ determined there was not a significant difference between members of the market association and market status. The chi-square analysis $(\chi=.11, \mathrm{df}=1)$ determined there was not a significant difference between market manager and market status (see Table 38). In each case the researcher failed to reject the null hypothesis. All the variables were independent. 
Table 38

Chi-Square Analysis - Farmers' Market Management Structure by Market Economic Status

\begin{tabular}{|c|c|c|c|c|c|c|}
\hline & & \multicolumn{2}{|c|}{ Market Status } & \multirow[t]{2}{*}{ Value } & \multirow[t]{2}{*}{ df } & \multirow[t]{2}{*}{ Sig. } \\
\hline & & Struggling & Successful & & & \\
\hline \multirow[t]{2}{*}{$\begin{array}{l}\text { State government } \\
\text { agency }\end{array}$} & Yes & 3 & 9 & & & \\
\hline & No & 16 & 25 & 0.794 & 1 & 0.373 \\
\hline \multirow{3}{*}{$\begin{array}{l}\text { City-county or } \\
\text { Municipal } \\
\text { government agency }\end{array}$} & & & & & & \\
\hline & Yes & 1 & 9 & & & \\
\hline & No & 18 & 25 & 3.581 & 1 & 0.058 \\
\hline \multirow[t]{2}{*}{$\begin{array}{l}\text { Producer-vendor } \\
\text { operated Board of } \\
\text { Directors }\end{array}$} & Yes & 4 & 12 & & & \\
\hline & No & 15 & 22 & 1.173 & 1 & 0.279 \\
\hline \multirow[t]{2}{*}{$\begin{array}{l}\text { Community } \\
\text { association-non- } \\
\text { profit organization }\end{array}$} & Yes & 2 & 2 & & & \\
\hline & No & 17 & 32 & 0.377 & 1 & 0.539 \\
\hline \multirow[t]{2}{*}{$\begin{array}{l}\text { Members of the } \\
\text { market association }\end{array}$} & Yes & 7 & 19 & & & \\
\hline & No & 12 & 15 & 1.768 & 1 & 0.184 \\
\hline \multirow[t]{2}{*}{ Market Manager } & Yes & 7 & 11 & & & \\
\hline & No & 12 & 23 & 0.11 & 1 & 0.741 \\
\hline
\end{tabular}




\section{Hypothesis \#2}

A chi-square test of independence was used to determine if there was a significant association between the variable paid market manager and market status. The following hypotheses were tested:

$\mathrm{H}_{\mathrm{o}}$ : The variables paid manager for farmers market and market economic success are independent.

$\mathrm{H}_{\mathrm{A}}$ : There is an association between paid manager for farmers market and market economic success.

The chi-square analysis $(\chi=.406, \mathrm{df}=1)$ determined there was not a significant difference between market manager and market status (see Table 39). The researcher failed to reject the null hypothesis. The variable paid market manager was independent.

Table 39

Chi-Square Analysis - Paid Market Manager and Market Status

\begin{tabular}{|c|c|c|c|c|c|c|}
\hline & & \multicolumn{2}{|c|}{ Market Status } & Value & $\mathrm{df}$ & Sig \\
\hline \multirow[t]{3}{*}{$\begin{array}{c}\text { Paid Market } \\
\text { Manager }\end{array}$} & & Struggling & Successful & & & \\
\hline & Unpaid & 13 & 26 & 0.406 & 1 & 0.524 \\
\hline & Paid & 6 & 8 & & & \\
\hline
\end{tabular}

Hypothesis \#3

The population for the study consisted of 53 markets reporting the salary status of their manager with 38 markets not paying their market manager and 15 paying their market manager. A t-test statistical procedure was used to determine if a statistical 
difference existed between the mean number of vendors in the two groups. The hypotheses tested were:

$\mathrm{H}_{\mathrm{o}}$ : The mean number of vendors is equal between managers who volunteer and those who are paid.

$H_{\wedge}$ : The mean number of vendors is not equal between managers who volunteer and those who are paid.

The mean number of vendors for the unpaid managers was 13.55 with a standard deviation of 10.454. The mean number of vendors for the paid managers was 62.40 with a standard deviation of 118.402 (see Table 40). Levene's test for equality of variance was significant therefore the equal variances not assumed analysis results were used.

An independent t-test statistical analysis procedure was used to compare the means of the unpaid and paid market managers. The statistical analysis results $(\mathrm{t}=$ $-1.595, \mathrm{df}=14.086)$ were not significant. Therefore the researcher failed to reject the null hypothesis: $\mathrm{H}_{\mathrm{o}}$ : The mean number of vendors is equal between managers who volunteer and those who are paid.

Table 40

Comparison of the Mean Scores of Paid Market Manager with Size of Farmers' Market

\begin{tabular}{ccccccc}
\hline & $\begin{array}{c}\text { Market } \\
\text { Manager }\end{array}$ & N & Mean & SD & df & t \\
\hline $\begin{array}{c}\text { Size of farmers } \\
\text { market }\end{array}$ & Unpaid & 38 & 13.55 & 10.454 & 14.086 & -1.595 \\
& Paid & 15 & 62.4 & 118.402 & & \\
\hline
\end{tabular}




\section{Hypothesis \#4:}

The population for the study consisted of 52 markets who reported the age of their market with 36 markets not paying their market manager and 16 paying their market manager. A t-test statistical procedure was used to determine if a statistical difference existed between in the mean age of the farmers market when compared by the "paid" status of the market manager.

The hypotheses tested were:

$\mathrm{H}_{\mathrm{o}}$ : The mean age of the market is equal between managers who volunteer and those who are paid.

$\mathrm{H}_{\mathrm{A}}$ : The mean age of the market is not equal between managers who volunteer and those who are paid.

The mean age of the market for unpaid managers was 10.5 with a standard deviation of 9.416. The mean age of the market for paid managers was 7.13 with a standard deviation of 5.149 (see Table 41).

An independent t-test statistical analysis procedure was used to compare the means of the unpaid and paid market managers. The statistical analysis results $(\mathrm{t}=$ $1.342, \mathrm{df}=50$ ) were not significant. The researcher failed to reject the null hypothesis $\mathrm{H}_{\mathrm{o}}$ : The mean age of the market is equal between managers who volunteer and those who are paid. 
Table 41

Comparison of the Mean Scores of Paid Market Manager with Age of Farmers' Market

\begin{tabular}{ccccccc}
\hline & $\begin{array}{c}\text { Market } \\
\text { Manager }\end{array}$ & N & Mean & SD & df & $\mathrm{t}$ \\
\hline $\begin{array}{c}\text { Age of farmers } \\
\text { market }\end{array}$ & Unpaid & 36 & 10.5 & 9.416 & 50 & 1.342 \\
& Paid & 16 & 7.13 & 5.149 & \\
\hline
\end{tabular}

Discriminant Analysis

A stepwise discriminant analysis was conducted on the data to determine the best discriminators among "years of operation, total producer-vendor sales, number of producers, advertising budget, full time year round, part time seasonal, part time year round, and volunteers" as an influence on market status. The eight discriminators were used as potential discriminating variables in the statistical procedure. The null hypothesis tested was there would be no impact by the discriminators between the group centroids on the discriminant scores. At an alpha level of $\leq .05$, the null hypothesis was rejected on the discriminator "years of operation" and the research hypothesis was accepted that the discriminator did have an impact on "market status." None of the other discriminators loaded into the equation.

One factor, years of operation, loaded on the discriminant function when analyzed by their structure coefficients. The group centroids for not checked and checked were -.575 and .372 (see Table 42). The canonical discriminant function coefficients for each attribute were 1.000 . 
To determine the similarity between a single variable and a discriminant function, the structure coefficient was examined. The structure coefficient was 1.000 signifying that the function was carrying nearly the same information as the variable (Klecka, 1980).

The Wilks' Lambda is a multivariate measure of the group difference over the discriminating variables (Klecka, 1980). Values of the lambda which approach zero indicate high discrimination. The analysis resulted in a Wilks' Lambda of .813 indicated that 81.3 percent of the variance was unexplained. The eigenvalue of .230 indicated that the discriminant function can explain only .230 times as much as not being explained.

The canonical correlation coefficient is used to examine the relationship between the sets of variables. A large coefficient indicates a strong relationship between the groups and the discriminant function (Klecka, 1980). The canonical correlation coefficient was .433 .

Table 42

Summary Data: Discriminant Analysis of Discriminating Variables

\begin{tabular}{lc}
\hline Statistic & Value \\
\hline Centroids & -0.575 \\
\multicolumn{1}{c}{ Beginning, struggling, started not a factor } & 0.372 \\
Sustaining, successful a factor & 1.000 \\
Standardized canonical discriminant function coefficient & 1.000 \\
Structure coefficient & 0.433 \\
Canonical correlation coefficient (Rc) & 0.230 \\
Eigenvalue & 0.813 \\
Wilks' Lambda & \\
\hline
\end{tabular}

$*_{\alpha} \leq .05$ 
The classification analysis results found that 66.0 percent of the original group cases were correctly classified (see Table 43). Based on the sustaining-successful factor, the researcher can predict with 66.0 percent accuracy the market status.

In looking at the predicted groups, the numbers were nearly the same between the beginning-started groups, but the difference occurs when examining sustainingsuccessful factor. Here the 32 cases are evenly split between beginning-started and sustaining-successful groups. Years of operation is the classification which influenced the 16 cases that consider themselves as sustaining-successful in market status. The cases where years of operation classification did influence the market status would indicate that these markets were probably at the average years of operation or older.

Table 43

Classification of Cases Based on Discriminant Analysis and Years of Operation

\begin{tabular}{|c|c|c|}
\hline Group & No. of Cases & Predicted Group \\
\hline
\end{tabular}

Beginning-started status not a Factor

Number

$\%$

Sustaining-successful status a Factor

Number

$\%$
18

17

94.4

32

16

50.0
1

5.6

Percent of Cases Correctly Classified: $66.0 \%$ 


\section{CHAPTER V}

\section{Summary, Conclusions, and Recommendations}

\section{Purpose and Objectives of the Study}

The purpose of this study is reflected in the following research questions:

1) Is there an association between the farmers' market management structure (manager, board of directors, or volunteers) and the economic success of West Virginia farmers markets?

2) Is there an association between the volunteer/paid status of the manager and the markets economic success?

3) Is there an association between the size of the farmers' market and the volunteer/paid status of the manager?

4) Is there an association between the age of the farmers' market and the volunteer/paid status of the manager?

The information gained as a result of this study will provide a foundation for recommendations regarding farmers' market organization and planning that may enhance the success and longevity of individual farmers markets. In addition this information will be utilized in educational materials to benefit farmers' market managers, board of directors, and others who assist with current management and strategic planning for farmers markets. 


\section{Population}

This study included all the farmers' markets in WV that were operating in 2012. A total of 90 survey packets were mailed on the initial mailing based on the data base that had been compiled from various agencies. It was determined by returns and e-mail responses that seven of the markets had closed or ceased to operate in 2012 . We received two new markets that were not on any database used. This gave a total population of 85 farmers markets with 56 markets responding for a 65.88 percent rate of return. In addressing the non-response error we found that one question was statistically significant, therefore we limited generalizations to the 52 respondents.

\section{Summary and Discussion}

Part 1 - Market Operations, Questions \#1 - 11

The farmers' markets in WV averaged 9.46 years of operation with the range being from one to 30 years of operation. With six markets operating over 20 years, the majority of the farmers markets are somewhere between beginning years and developing into economically self-supporting organizations.

The markets were open the months of June through October. In July and August all of the markets were operating and a small number operated during the winter months of November through April. Sixty percent of the markets operated one day a week with 35 percent operating two days a week. The farmers' markets operated on a typical growing season for this state.

Financing of 34 farmers' markets (69\%) was done by producer/vendor fees. Fifty percent of the farmers' markets were being financed by government entities, non-profit 
organization, farmers' market association, or a trade or business association. The "other category" included sale plus commission, outside funding source, grant funding, donations and fundraisers, free use of local fairgrounds, or manager finances.

Average sales at farmers' market were $\$ 48,935.02$ for 2012 year. The range of sales was from $\$ 500.00$ to $\$ 450,000.00$. Approximately one fourth of the markets did not report producer/vendor sales for their market. Without good information on sales in the market how can good economic decisions be made by the governing entity?

Market sales were generated by retail sales predominantly with a few of the markets doing wholesale sales. The number of producers selling at least one time from the farmers market averaged 27. Ninety-eight percent of the sales were retail with 8 percent wholesale sales. Since many of the farmers markets are located near or in urban areas, this researcher would have expected to see more wholesale sales.

The number one product a majority of the producers/vendors sold was fresh fruits and vegetables. This was followed closely by honey, nuts, jams, jellies, and preserves; baked goods; and herbs, flowers, and plants. These results are similar to the USDA Agricultural Marketing Services 2006 National Farmers Market Survey (Ragland and Tropp, 2009).

The label "locally grown" was used by 90 percent of the producers/vendors for selling their products. Other labels such as "pasture raised - free range - cage free" or "chemical free - pesticide free" were used 40 percent and 39 percent of the producers/vendors respectively. The labels of "Certified USDA Organic" and "Certified Naturally Grown" were used by less than 10 percent of the farmers markets. Based on this data the supply of this type of production is less than other parts of the United States. 
Managers of the farmers markets reported the number one market restriction used is "produced themselves." In order to get into their market the producer/vendor has to raise the items they want to market. Producer being allowed to "resell other local products" was the second factor limiting entrance to the market. "Product mix" being sold was used by less than 10 percent of the farmers markets as a market restriction. A producer needs to raise the products they want to market in order to be considered for admittance in 32 of the farmers markets. Since product mix is not being used as a market restriction for admittance to the market, there are multiple producers/vendors with the same items for sale.

The leading reason (78\%) given for customers shopping at the market was "freshness and condition of product." There was a twenty percent drop to the second reason $(57 \%)$ which was "access to locally produced food." Other reasons $(53 \%)$ included "support of local agriculture." Customers have expressed their preference in the market place on "freshness and condition of the product" to the point that managers and producers rank this as the top reason for shopping in their farmers market. Quality of the product is the top concern for the customers when shopping at the farmers market.

\section{Part 2 - Market Management - Questions \#12 - 28}

In asking the markets if they had a permanent location, 51 (91.1\%) managers said yes. This was a higher percentage than expected due to some markets being in their early years of operation.

The farmers' markets were asked to define themselves based on a selection of the following areas: beginning, struggling, getting started, sustaining and successful. Twenty 
markets (37.7\%) considered themselves as successful and 14 markets (26.4\%) considered themselves as sustaining. The remaining 19 markets were broken down as follows: nine (17\%) struggling; six (11.3\%) getting started; and four (7.5\%) beginning. This indicates that 60 percent of the markets in the state are covering their operating cost with some having extra funds. The other 40 percent is in the phase of just beginning or getting started with their farmers' markets.

A list was provided for the managers to rate the methods they used for advertising. The top five categories were: signs-banners on market day or during season (37\%), social media (32.7\%), newspaper (26.5\%), brochures-flyers (18\%), and newsletter (15.7\%). Based on these results it shows that market managers need to be looking at the methods they use to advertise including social media. Even with WV being a predominantly rural state with broad band service unavailable in large sections of the state, the farmers markets are using social media to get the word out to their customers.

When the markets were asked to provide an amount used for their annual budget as well as their advertising budgets the average was $\$ 2,015.86$ and $\$ 740.37$ respectively. The maximum amount spent for annual budget was $\$ 15,000.00$ and the maximum advertising budget was $\$ 12,000.00$. This indicates many markets have limited funds to use. Since we saw social media ranked highly in advertising, this could also possibly explain how many of the markets are advertising that have few or no funds.

To see how the market managers are getting feedback from their customers we asked if their market conducted periodic surveys to assess customer preferences. Twenty-four (46.2\%) of the farmers markets did conduct periodic customer surveys to assess their customer preferences, but 28 (53.8\%) did not conduct periodic customer 
surveys. Since it is nearly even between the markets that do conduct surveys and those that do not, it shows that half of the markets either do not assess their customers to find out their preferences or are using some other method to obtain that information.

Types of fees the farmers' markets used went from no fee to $\$ 100.00$ per season and everything in between. No fee accounted for 32.1 percent of the markets and membership fee covered 26.8 percent of the markets. Various other fees were reported for the remaining markets. Seeing that one third of the markets have no fee for selling helps explain why they also have no annual budget or advertising funds. This would make it difficult to operate except with volunteers and word of mouth for promotion.

Twenty-four (52.2\%) of the 46 markets indicating the work status of their market manager was part time seasonal (works only when market is open). This corresponds with the work done by Govindasamy et al. (1998) where they found that market managers were employed by different sources and worked normally when the markets were open. Part time year manager was reported working in 10 (21.7\%) markets. Full time seasonal manager was reported in four (8.7\%) markets with eight (17.4\%) markets having full time year round manager. One-fourth of the farmers markets have been able to economically afford to have a full time year round or full time seasonal manager in 2012.

The farmers' market managers were asked to respond to a series of questions that addressed how many workers were employed in their market and the times of year they were employed. Thirty-three markets used an average of 2.6 volunteers per market. This accounted for approximately 60 percent of the farmers' markets operations. The categories of employed "full-time seasonal" and "part-time seasonal" each was used by 
approximately 20 percent of the farmers' markets. The remaining markets either employed "year round" or "part time year round" workers in their markets. These findings are consistent with the results of Oberholtzer and Grow (2003) from their study of producer only markets in a 10 county area of Pennsylvania, Maryland, and Washington, D.C. where a large percentage of the market managers were volunteers.

Twelve different operational issues were listed for the manager to choose from when selecting the top three areas needing improvement. The top three operational issues needing improvement were: 1) customer number (50\%), 2) advertising-publicity (44.6\%), and 3) low sales per producer/vendor (35.7\%). This researcher expected to see operational issues of development of a business plan for the market and liability insurance coverage in the top three. Development of a business plan was listed by 25 percent and liability insurance coverage was listed by 19.6 percent of the markets as needs for improvement.

Rules, regulations, and producer/vendor criteria for the market were developed by "members of the market association" in nearly fifty percent of the situations followed by "market manager" (34.5\%) and "producer vendor operated board of directors" (30.9\%). The National Farmers Market Manager Survey 2006 (Ragland \& Troop, 2006) found that rules were made 36.6 percent of the time by the market manager and 32 percent of the time by vendor operated board of directors.

In looking at types of market assistance to improve your market's producers/vendors sales, 66.1 percent of the market managers said training on merchandising retail displays. The other types of market assistance listed by over one fourth of the markets were: research on local customer demographics and preference 
(55.4\%), training on business plan development (39.3\%), and improvement in layout of facility $(25.0 \%)$. All of these are resources should be obtainable from local county extension offices, community colleges, small business associations, or economic development offices. Within some regions of the state all of these types of assistance may not be available in their local community.

The statement "we have more demand than supply" (44.2\%) was reported by 23 farmers markets in 2012. The remaining markets were almost evenly split between the statements "we have more supply that demand" (26.9\%) and "our supply and demand are roughly equal" (28.8\%).

Part \#3 - Producer/vendor information - Questions \# 29 - 38

This section of the survey had to do with the various social programs that are available to the producer/vendors, if they participated, and how much sales value resulted. The three programs asked about the Women, Infants, and Children Farmers Nutrition Program (WICFNP), Senior Farmers Market Nutrition Program (SFMNP), and SNAP using the Electronic Benefit Transfer (EBT) program. All of these programs provide funding to individuals that meet their qualifications and are to be used for fresh produce and fruits at farmers' markets. The highest program participation was in the SFMNP program by 48 markets (87.3\%) with an average sales value of $\$ 1,193.78$. Twenty-three of the 48 farmers' markets reported their sales value with a minimum sale of $\$ 30.00$ to a maximum sale of $\$ 7,000.00$. Thirty-three markets $(61.1 \%)$ participated in the WICFMNP program with 31 of the markets reporting sales. Average sales were $\$ 602.40$ with a minimum sale of $\$ 0.00$ and a maximum sale of $\$ 4,000.00$. SNAP using 
EBT was used in nine markets (18.2\%) with an average sale of $\$ 524.93$ having a minimum sale of $\$ 0.00$ and a maximum sale of $\$ 1,761.00$. The managers were asked if the market used credit-debit card sales. Credit-debit card sales were reported for seven farmers' markets $(13.5 \%)$. The data shows a majority of the producers/vendors in the farmers markets are accepting the various government funded programs. What was surprising is the low amount of participation being reported for the SNAP and creditdebit cards considering many of the government programs have or will be going paperless.

\section{Part 4 - Market Manager - Questions 39 - 49}

Each respondent was asked what the duties of their market manager were. Several duties were provided for them to select and they were to check all that applied. Forty-four (88\%) of the 56 markets responded with the top duty being "settling disputes, handling problems." Other market manager duties reported included: opening and closing the market (78\%), public relations spokesperson for the market (76\%), advertising (70\%), dealing with regulations $(60 \%)$, assigning vendor spaces in the market (58\%), and collecting data (52\%). Other duties they performed included keeping financial records, managing websites, newsletter, social media, promoting food safety, writing grants, farm inspections, operating EBT machine, etc. The market managers have a wide range of duties they perform in the markets. Stephenson, Lev, \& Brewer (2007) in examining the link between farmers market size and management structure found that a large market without any management structure or organization would be chaos. Considering the number one duty was dealing with settling disputes and handling 
problems, does the lack of management structure contribute to this being the number one duty for market managers? Stephenson et al. (2006) stated that much of the ability to excel in key traits of a successful farmers' market is based on the use of management tools. Based on the results of this study the manager has to have the ability to handle multiple tasks at the same time. The market manager is dealing with the atmosphere, community, and product in creating a successful market operation. The market manager has to have the management skills to blend the producers/vendors and customers within the atmosphere, community and product of which they are operating to result in a successful farmers market. Manville (2010) stated the individual needs to have several areas of strength and management ability to deal with the various responsibilities of a market manager.

Only $14(26.9 \%)$ markets have a written job description for their market manager. From the 52 markets that reported, the majority (73.1\%) did not have a written job description for the market manager. By not having a written job description, how does the manager know what is expected of them and what criteria do the board of directors' use when evaluating their manager. This researcher was surprised at this response because the market manager is such a vital position in the success of the market.

Markets managers indicated they had some written documents in their organizations. The number one written document was market rules $(88 \%)$. This was the only written document that was common among the markets. By-Laws were the other written document that 50 percent of the markets had. Written documents they did not have to any degree were: constitution (94\%), grievance policy (82\%), and product list 
(68\%). Stephenson, Lev, \& Brewer (2007) found that market rules were at the core of a well-managed market.

Gender of the market manager was nearly evenly split between male and female. Gender of the managers at the farmers market included 26 (52\%) markets with female managers and $20(40 \%)$ markets with male managers. Four $(8 \%)$ of the markets had both male and female managers working.

In looking at the age of the manager for the markets the age ranges of 51-60 (27.3\%) and 41-50 (25.5\%) accounted for 50 percent of the markets. The 60 and over age range followed at 23.6 percent of the markets. There were no mangers under the age of 20. Govindasamy et al. (1998) found the average age of the managers was 45. This study shows the market manager age range for farmers markets in WV is in the 41-60 range for 50 percent of the markets with a higher number in the 51-60 age range.

When examining the manager's years of experience nearly 50 percent (46.9\%) of the managers had between 1-5 years. Twelve, 24.5\%, of the managers had 6-10 years of experience. There was seven, $14.3 \%$, of the managers with less than one year of experience. Managers in WV farmers markets have five years or less experience in 60 percent of the farmers markets that operated in 2012. This indicates they are learning as they manage due to limited work experience.

Nearly 70 percent of the managers working in farmers markets had a Bachelor's degree or less educational experience. Twenty managers reported having a Bachelor's degree (38.5\%) with sixteen reporting a High School Diploma or equivalent degree (30.8\%). Fourteen individuals had a Master's degree (26.9\%) and one (1.9\%) market had a manager with a Doctoral degree. 
Out of the 56 markets only 16 (28.57\%) markets reported to be paying a market manager. Forty markets $(71.4 \%)$ are not paying their managers any salary at all. The salary paid to the manager ranged from less than $\$ 1,000.00$ to over $\$ 10,000.00$ with 50 percent of the markets paying $\$ 2,000.00$ or less. One-third of the markets reporting paid over $\$ 5,000.00$ to their managers.

The managers were asked if the market manager has the authority to enforce the market rules and does she/he supply demographic data on potential new market locations. In 93.9 percent of the markets the manager has the authority to enforce the market rules. Twenty-three markets (52.3\%) indicating their manager supplied demographic data on potential market locations.

The leading source of information for market managers was the local Extension agent (88.2\%). Other sources of information included the WV Department of Agriculture (64.7\%), local Health Departments (60.8\%), WV Farmers Market Association (52.9\%) and the WV Small Farm Center (49\%). Other contacts were made with local government agencies and local economic development organizations.

\section{Hypotheses Questions}

There was not a significant difference between any of the management structure variables (state government agency, city-county or municipal government agency, producer/vendor operated board of directors, community association-non-profit organization, members of the market association, market manager) and market status. Chi-square analyses were used to examine the association between funding sources and status of the organization. 
There was not a significant difference between paid market manager and market status. A chi-square test of independence was also used to determine if there was an association between the variable paid market manager and market status.

Size of the farmers' market as measured by the number of vendors was not different when compared by the fact that the manager was a volunteer or paid. An independent t-test statistical procedure was used to compare the mean number of vendors for the unpaid and paid market managers. The statistical analysis results were not significant.

There was no difference in the age of the farmers' market when compared by the fact that the manager was a volunteer or paid. An independent t-test statistical procedure was used to compare the mean market age of the unpaid and paid market managers. The statistical analysis results were not significant.

\section{Conclusions}

In reviewing all the summaries from the survey we are only able to say "years of operation" was the factor that proved to impact "market status" statistically. All of the other variables examined did not demonstrate any significant difference on the dependent variable "market status."

In comparing the results with previous research there were several variables which seemed to be common in the markets that were successful. In the following areas we obtained results similar to previous researchers:

- Top products sold were fresh fruits and vegetables; honey, nuts jams, jellies and preserves; baked goods; and herbs, flowers, and plants 
- Large percent of the employment was volunteers

- Governing body of farmers' markets was members of the market association, market manager, and producer board of directors

- Market manager needs to have several areas of strength and management ability

- Market rules were at the core of a well-managed market

- Average age of the market manager was in the 41-60 age range.

These results were in line with the work done by Ragland and Troop, 2006;

Govindasamy et al., 1998; Oberholtzer and Grow, 2003; Manville, 2010; and Stephenson, Lev, and Brewer, 2007. Management Structure Impact on Economic Success of Farmers Markets was not a significant factor in the economic success of the markets.

\section{Recommendations}

The findings of this study have provided a basis from which to start to understand the functions of farmers markets operating in WV. There are many areas of unknown information that can be explored in future studies and areas where training and/or information needs to be provided to assist market managers. Based on these findings, the following recommendations are made:

- The information identified in this study should be appropriately communicated to groups and individuals such as all West Virginia University Extension Service units, farmers' market managers/board of directors, and community development professionals. 
- West Virginia University Extension Service needs to develop or provide the following:

- information for market managers to use in training their producers on merchandising of product

- local demographic information on their area

- training on how to do a business plan

- training on how to interact with the public when doing sales

- training on how to do advertising of the markets

- information on how to get liability insurance for the producers and market.

- Conduct a study of why the farmers markets are not capturing a larger share of the dollars from the various government social programs.

- Conduct an in-depth qualitative study of the interactions the market manager has with the community, atmosphere, and products that are in the market place.

- Conduct a study of the successful farmers markets to determine what the main factors are that have contributed to their economic success. 


\section{REFERENCES}

Ary, D., Jacobs, L. C., \& Sorensen, C. (2010). Introduction to Reserach in Education. Belmont, CA, United States: Wadesworth.

Bachmann, J. (2008). Farmers' markets: marketing and business guide. Retrieved September 21, 2010, from ATTRA - National Agriculture Information Service: www.attra.ncat.org/attra-pub/PDF/farmmarket.pdf

Dillman, D., Smyth, J., \& Christian, L. (2009). Internet, mail and mixed-mode surveys: The tailored design method (3rd ed.). New York: Wiley.

Govindasamy, R., Italia, J., \& Adeaja, A. (2002, February). Farmers' Markets: Consumer Trends, Preferences, and Characteristics. Journal of Extension, Volume 40(Number 1, Research in Brief, 1RIB6).

Govindasamy, R., Zurbriggen, M., Adelaga, A., Italia, J., Nitzsche, P., \& VanVranken, R. (1988). Farmers markets: managers characteristic and factors affecting market organization. Rutgers, The State University of New Jersey. New Brunswick: New Jersey Agricultural Experiment Station P-02137-8-98.

Guptill, A., \& Wilkins, J. (2002). "Buying into the Food System: Trends in Food Retailing in the U.S. and Implications for Local Foods. Agriculture and Human Values, Vol. 19, pp. 39-51.

Hughes, D., et al. (2007). What is the Deal with Local Food Systemns: Or, Local Food Systems from a Regional Perspective. Working Paper 11-2007-01, Clemson University, Clemson, SC.

Ilbery, B., \& Maye, D. (2005). "Food Supply Chains and Sustainability: Evidence from Specialist Food Pfoducers in the Scottish/English Borders". Land Use Policy, Vol. 22, pp. 331-344.

Jolly, D. (2005). Farmers market management skills (Vol. 2). Davis, CA: UC Small Farm Center.

Klecka, W. (1980). In Discriminant analysis: Quantitative applications in the social sciences. London: Sage Publications.

Mainville, D. (2010, April 27). Foundations for a successful farmers' market. Retrieved September 21, 2010, from Virginia Tech Extension Service: www.pubs.ext.vt.edu/448/448-502/448-502.html 
Oberholtzer, L., \& Grow, S. (2003, October). Producer-only farmers' markets in the midatlantic region. Retrieved September 21, 2010, from Henry A. Wallace Center for Agricutltural and Environmental Policy: http://www.winrock.org/wallace

Pirog, R. (2009). Local Foods: Farm Fresh and Environmentally Friendly. http://www.leopold.iastate.edu/research/marketing_files/WorldBook.pdf.

Pyle, J. (1971). Farmers' Markets in the United Sates: Functional Anachronisms? Geographical Review, 61(2), pp. 167-197.

Ragland, E., \& Tropp, D. (2006, May). National farmers market manager survey 2006. Retrieved September 21, 2010, from Agricultural Marketing Service: www.ams.usda.gov/AMSv1.0/getfile?dDocName=STELPRDC5077203

Ragland, E., \& Tropp, D. (2009). National farmers market manager survey 2006. Retrieved February 2012, from Agricultural Marketing Service: www.ams.usda.gov/AMSv1.0/getfile?dDocName=STELPRDC5077203

Representatives, U. H. (1975). Farmer-to-Consumer Direct Marketing: Hearing before the Subcommittee on Domestic Marketing and Consumer Relations of the Committee on Agriculture. 94th Congress Washington, D.C.: U.S. Government Printing Office.

Robinson, J., Shaver, P., \& Wrightsman, L. (1991). Measures of personality and social psychological attitudes. New York: Academic Press.

Stephenson, G. (2008). Farmers' markets: success, failure and management ecology. Amherst, NY: Cambria Press.

Stephenson, G., Lev, L., \& Brewer, L. (2006). Enhancing the success of northwest farmers' markets. An executive summary. Retrieved September 21, 2010, from Oregon State University Extension Service: www.smallfarms.orgeonstate.edu/sites/default/files/TechReport22.pdf

Stephenson, G., Lev, L., \& Brewer, L. (2007, December). Understanding the link between farmer's market size and management organization. Retrieved September 21, 2010, from Oregon State Extension Service: http://extension.oregonstate.edu/catalog/pdf/sr/sr1082.pdf

Wann, J. L., Cake, E., Elliott, W., \& Burdette, R. (1948). Farmers, Produce Markets in the United Sates, Part 1, History and Description. Marketing Research Report No. 17. Washington, D.C.: U.S. Department of Agriculture, Farm Credit Administration. 
Webber, D. (2010). How to organize and run a successful farmers' market. Retrieved September 21, 2010, from Mass.Gov.org: www.mass.gov/agr/markets/farmersmarkets/start_a_market.htm

Zimet, D., Hewitt, T., \& Henry, G. (1986). Proceedings Flordia State Horticulture Society 99. Characteristics of successful vegetable farmers' retail markets, (pp. 291-293). 
APPENDICES 
APPENDIX A

Pilot Test Letter 
March 1, 2013

Dear Larry:

I am H.R. Scott, a graduate student in Agricultural and Extension Education; and under the direction of my advisor, Dr. Harry N. Boone, Jr., we are conducting this study to determine the management styles that are being used in farmers' markets across West Virginia. The study will also identify markets that have paid managers. The results of this study will be used to prepare a dissertation to partially fulfill the requirements for a Doctorate in Agricultural and Extension Education.

Enclosed is my doctoral survey instrument that you have agreed to pilot test for us. Please complete the questionnaire to be the best of your knowledge if you do not have exact figures. Time yourself and write that information at the end along with any concerns you have with question wording, clarity, or comprehension of what is being asked.

We are contacting managers of farmers' markets in West Virginia for this study. The results will provide insight for many groups of people, including market managers, boards of directors for markets, Extension Service Agents and community organizations. The results will be used to assist community organizations, Extension Agents, and economic development organizations develop markets. Please take a few moments and share your opinions with us.

Participation in this research study is completely voluntary and all information you provide will be held as confidential as possible. The survey should only take about twenty minutes to complete, and your response to the survey is crucial to the success of the study. You may skip any question you are not comfortable answering and you can stop at any time. You will notice a code number at the top left of the return envelope. This code will be used to identify non-respondents for follow-up and will be destroyed before the data are analyzed. Survey results will be reported in a summary format and individual responses will not be identifiable.

The Institutional Review Board (IRB) at West Virginia University has approved this study. If you have any questions or concerns about completing the questionnaire or about being in this study, you may contact me at HRScott@mail.wvu.edu or 304-291-7201.

Place the completed questionnaire in the enclosed postage-paid self-addressed return envelope and drop it in the mail. Please return your completed questionnaire before March 15, 2013. Thank you in advance for your assistance with this research effort. We sincerely appreciate your participation.

Sincerely,

H.R. Scott

Doctoral Student

Extension Service
Harry N. Boone, Jr., Ph.D.

Professor and Chair

Agricultural and Extension Education 


\section{APPENDIX B}

Initial Mailing Cover Letter 
April 15, 2013

Dear Market Manager:

As a manager you are a vital part of the West Virginia Farmers' market system. As a market manager, your area of responsibility covers several phases of the management structure, such as vendors, customers, advertising, marketing, rules, and applications, to name a few. The management structure is critical to the economic success of your market.

I am H.R. Scott, a graduate student in Agricultural and Extension Education; and under the direction of my advisor, Dr. Harry N. Boone, Jr., we are conducting this study to determine the management styles that are being used in farmers' markets across West Virginia. The study will also identify markets that have paid managers. The results of this study will be used to prepare a dissertation to partially fulfill the requirements for a Doctorate in Agricultural and Extension Education.

We are contacting managers of farmers' markets in West Virginia for this study. The results will provide insight for many groups of people, including market managers, boards of directors for markets, Extension Service Agents and community organizations. The results will be used to assist community organizations, Extension Agents, and economic development organizations develop markets. Please take a few moments and share your opinions with us.

Participation in this research study is completely voluntary and all information you provide will be held as confidential as possible. The survey should only take about twenty minutes to complete, and your response to the survey is crucial to the success of the study. You may skip any question you are not comfortable answering and you can stop at any time. You will notice a code number at the top left of the return envelope. This code will be used to identify non-respondents for follow-up and will be destroyed before the data are analyzed. Survey results will be reported in a summary format and individual responses will not be identifiable.

The Institutional Review Board (IRB) at West Virginia University has approved this study. If you have any questions or concerns about completing the questionnaire or about participating in this study, you may contact me at HRScott@mail.wvu.edu or 304-291-7201.

Place the completed questionnaire in the enclosed postage-paid self-addressed return envelope and drop it in the mail. Please return your completed questionnaire before May 1, 2013. Thank you in advance for your assistance with this research effort. We sincerely appreciate your participation.

Sincerely,

H.R. Scott

Doctoral Student

Extension Service
Harry N. Boone, Jr., Ph.D.

Professor and Chair

Agricultural and Extension Education 


\section{APPENDIX C}

Second Mailing Cover Letter 
May 15, 2013

Dear Market Manager:

During the last few weeks, we have sent you several mailings about an important research study we are conducting. Its purpose is to help us understand how farmers' markets are managed. Unless the response is in the mail, we have not heard from you. Hearing from everyone in our small statewide research population helps assure that the survey results represent the views of all market managers. As a manager you are a vital part of the West Virginia Farmers' market system. As a market manager, your area of responsibility covers several phases of the management structure, such as vendors, customers, advertising, marketing, rules, and applications, to name a few. The management structure is critical to the economic success of your market.

I am H.R. Scott, a graduate student in Agricultural and Extension Education; and under the direction of my advisor, Dr. Harry N. Boone, Jr., we are conducting this study to determine the management styles that are being used in farmers' markets across West Virginia. The study will also identify markets that have paid managers. The results of this study will be used to prepare a dissertation to partially fulfill the requirements for a Doctorate in Agricultural and Extension Education.

We are contacting managers of farmers' markets in West Virginia for this study. The results will provide insight for many groups of people, including market managers, boards of directors for markets, Extension Service Agents and community organizations. The results will be used to assist community organizations, Extension Agents, and economic development organizations develop markets. Please take a few minutes and share your opinions with us.

Participation in this research study is completely voluntary and all information you provide will be held as confidential as possible. The survey should only take about twenty minutes to complete, and your response to the survey is crucial to the success of the study. You may skip any question you are not comfortable answering and you can stop at any time. You will notice a code number at the top left of the return envelope. This code will be used to identify non-respondents for follow-up and will be destroyed before the data are analyzed. Survey results will be reported in a summary format and individual responses will not be identifiable.

The Institutional Review Board (IRB) at West Virginia University has approved this study. If you have any questions or concerns about completing the questionnaire or about being in this study, you may contact me at HRScott@mail.wvu.edu or 304-291-7201. Place the completed questionnaire in the enclosed postage-paid self-addressed return envelope and drop it in the mail. Please return your completed questionnaire before April 1, 2013. Thank you in advance for your assistance with this research effort. We sincerely appreciate your participation.

Sincerely,

H.R. Scott

Doctoral Student

Extension Service
Harry N. Boone, Jr., Ph.D.

Professor and Chair

Agricultural and Extension Education 


\section{APPENDIX D}

Initial Follow-up Postcard 
Last week a survey was mailed to you seeking your opinions about various phases of your farmers' market operations. You were asked to return it by May 1, 2013.

If you have already completed and returned the survey to us, please accept our sincere thanks. If not, please do so today. We are especially grateful for your help because it is only by asking people like you to share your personal opinions that we can understand how farmers' markets are managed. WVU's Institutional Review Board (IRB) acknowledgment is on file.

If you did not receive a survey, or if it was misplaced, please call 304-291-7201 or e-mail hrscott@mail.wvu.edu and we will mail you another one immediately. 


\section{APPENDIX E}

Follow-up Postcard 
During the few weeks, we have sent you several mailings about an important research study we are conducting on how farmers' markets are managed in West Virginia. The results will provide insight for many groups of people, including market managers, boards of directors for markets, Extension Service Agents and community organizations. The results will be used to assist community organizations, Extension Agents, and economic development organizations develop markets.

The study is drawing to a close and were are interested in securing your opinions. We want to assure you that your response to this study is voluntary and results will remain as confidential as possible. WVU's Institutional Review Board (IRB) acknowledgment is on file.

If you have already completed and returned the survey to us, please accept our sincere thanks. If not, please do so today. We are especially grateful for your help because it is only by asking people like you to share your personal opinions that we can understand how farmers' markets are managed.

If you did not receive a survey, or if it was misplaced, please call 304-291-7201 or e-mail hrscott@mail.wvu.edu and we will mail you another one immediately. 


\section{APPENDIX F}

Survey Instrument 


\title{
Management Structure Impact on Economic Success of Farmers' Markets
}

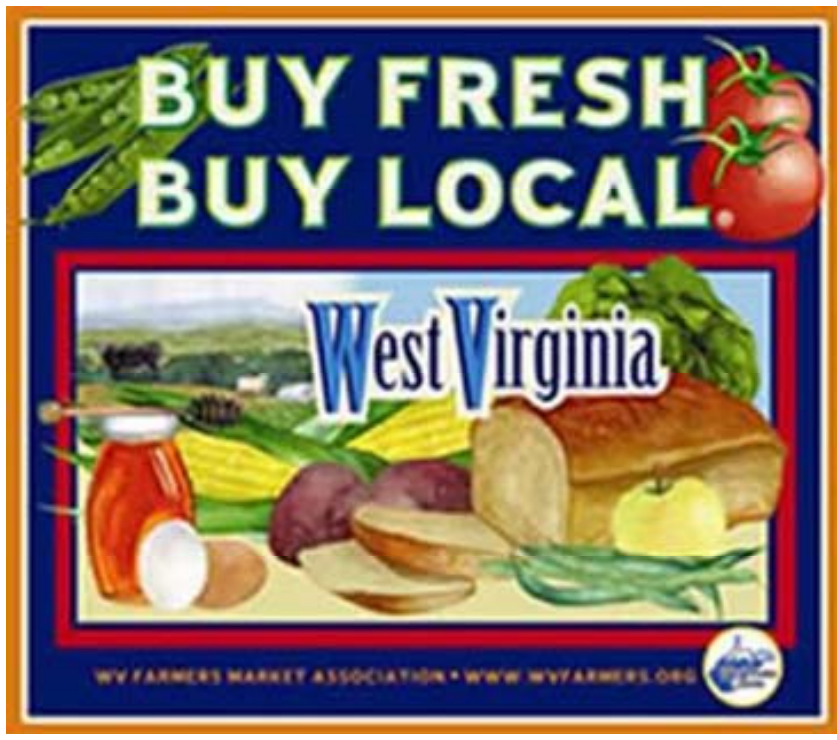

\author{
H. R. Scott \\ Doctoral Candidate \\ Agricultural and Extension Education \\ Division of Resource Management \\ Davis College of Agriculture, Natural Resources, and Design \\ West Virginia University \\ P.O. Box 6108 \\ Morgantown, WV 26506
}




\section{Management Structure Impact on Economic Success of Farmers' Markets}

Instructions: Please answer each question by filling in the blank or marking the appropriate answer. Some questions will have directions indicating how you are to respond.

NAME OF MARKET

PART 1 -- MARKET OPERATIONS

1. Including 2012, how many years has your market been in operation?

Years

2. What months is your market open? (Check all that apply)

January
February
March
April
May
June
July
August
September
October
November
December

3. What are your times of operation? (Select the one that represents your market best)

__ Weekly (one day each week)

Two days a week

Once a month

Twice a month 
4. How did your market finance its operations in 2012? (Please indicate the percentage provided by each funding source next to the appropriate label; the total percentage from all sources should add up to $100 \%$ )

Producer/vendor fees

State government agency

City/county municipal government agency

Non-profit organization

Farmers market association

Trade or business association (e.g., Chamber of Commerce)

Other (please specify):

5. How much was total producer/vendor sales at your market in 2012? (Please estimate if you do not know the exact figure.)

$\$$

6. On average in 2012, what percentage of market sales were generated by the following types of market patrons? (Please estimate if you do not know the exact percentage.)

$\%$ Retail sales? (direct to consumers)

$\%$ Wholesale sales? (restaurants, businesses, and/or institutions)

7. How many producers/vendors sold at least once at your market in 2012 ?

8. Please indicate the number of producers/vendors, who sold products at your market in 2012 .

\begin{tabular}{|l|l|}
\hline & $\begin{array}{c}\text { Total number of } \\
\text { producers/vendors }\end{array}$ \\
\hline Fresh fruits and vegetables & \\
\hline Milk and/or dairy products & \\
\hline Meat, eggs, and/or poultry products & \\
\hline Fish and/or seafood & \\
\hline Herbs, flowers, and plants & \\
\hline Honey, nuts, jams, jellies, and preserves & \\
\hline Baked goods & \\
\hline Prepared food (for immediate consumption) & \\
\hline
\end{tabular}




\begin{tabular}{|l|l|}
\hline Other processed foods & \\
\hline Crafts/woodworking & \\
\hline Other (please specify): & \\
\hline Other (please specify): & \\
\hline
\end{tabular}

9. What labels are used by producers/vendors to sell products? (check all that apply) Locally grown

\section{Certified USDA Organic}

Certified Naturally Grown

Pasture-raised/free range/cage free

Chemical-free/pesticide-free

Hormone-free/antibiotic-free

Other (please specify):

10. The following statements address market restrictions. Please circle your response as it relates to your market.

\begin{tabular}{|l|c|c|}
\hline $\begin{array}{l}\text { Agricultural producers are only allowed to sell farm products } \\
\text { they produce themselves at your market. }\end{array}$ & Yes & No \\
\hline Producers are allowed to resell other producers' farm products. & Yes & No \\
\hline Producers can sell farm products from outside the local area. & Yes & No \\
\hline $\begin{array}{l}\text { The range of items that can be sold at your market (e.g., meat, } \\
\text { eggs, vegetables, fruit, fish/seafood) is limited by the market. }\end{array}$ & Yes & No \\
\hline $\begin{array}{l}\text { Product mix at your market is controlled by limiting } \\
\text { producers/vendors to a certain number of the same product. }\end{array}$ & Yes & No \\
\hline
\end{tabular}

11. Please rank the top three reasons why you believe customers shopped at your market in 2012 . (Please select three items, and rank them 1 to 3, with 1 being the most important.)

Price

Freshness and condition of product

Taste and texture of product

Support of local agriculture

Variety of products offered

Access to locally produced food

Ability to know how food products are produced

Other (please specify): 


\section{PART 2 -- MARKET MANAGEMENT}

12. Does your market operate in a permanent location?

Yes

No

13. How do you define your market?

Beginning (2012 was first year of operation)

Struggling (more than one year of operation but not covering cost of operation)

Getting started (first to third year of operation)

Sustaining (third to fifth year of operation and covering cost)

Successful (five plus years operation, covering cost of operation and extra funds)

14. Please rate each of the following methods of advertising that your market currently uses. Please circle the appropriate number to indicate the effectiveness of that method. (Not

Effective 1-Very Effective 5)

\begin{tabular}{|c|c|c|c|c|c|c|}
\hline & 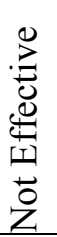 & & & & 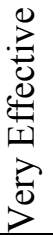 & $\begin{array}{l}\vec{D} \\
\mathscr{D} \\
0 \\
\ddot{0}\end{array}$ \\
\hline Newspaper & 1 & 2 & 3 & 4 & 5 & NA \\
\hline Radio & 1 & 2 & 3 & 4 & 5 & NA \\
\hline Television & 1 & 2 & 3 & 4 & 5 & NA \\
\hline Brochures/flyers & 1 & 2 & 3 & 4 & 5 & NA \\
\hline Direct mail & 1 & 2 & 3 & 4 & 5 & NA \\
\hline Newsletter & 1 & 2 & 3 & 4 & 5 & NA \\
\hline Signs/banners on market day or during season & 1 & 2 & 3 & 4 & 5 & NA \\
\hline Website & 1 & 2 & 3 & 4 & 5 & NA \\
\hline Social media (Facebook, Twitter) & 1 & 2 & 3 & 4 & 5 & NA \\
\hline Other (please specify): & 1 & 2 & 3 & 4 & 5 & NA \\
\hline
\end{tabular}


15. What was your market's annual operating budget in 2012 ?

$\$$

16. How much did your market spend on advertising in 2012 ?

$\$$

17. Does your market conduct periodic customer surveys to assess customer preferences?

Yes

No

18. What types of fees are producers/vendors charged to sell at your market? (check all that apply and provide amount of fee)

No fees charged

Flat rate of $\$ \_$per market

Percentage of sales _ $\%$

Farm inspection fee $\$$

Membership fee \$

Space fee $\$$

Other $\$$

19. Please indicate the work status of your market manager.

Part-time seasonal (works only when market is open)

Part-time year-round (works when market is open and when board requests)

Full-time seasonal (works only during market season)

Full-time year-round (works all year)

20. Including your market manager how many full-time seasonal workers does your market employ?

21. Including your market manager how many full-time year-round workers does your market employ?

22. Including your market manager how many part-time seasonal workers does your market employ? 
23. Including your market manager how many part-time year-round workers does your market employ?

24. Including your market manager how many volunteers work at your market?

25. Who develops rules, regulations, and producer/vendor criteria for your market? (check all that apply)
State government agency
City/county or municipal government agency
Producer/vendor-operated Board of Directors
Community association/non-profit organization
Members of the market association
Market manager
Other (please specify):

26. Please rank the top three operational issues that need improvement in your market? (Please select three items and rank them 1-3, with 1 being the most important.)

Customer number (low attendance)

Low sales per producer/vendor

Development of business plan for market

Advertising/publicity

Liability insurance coverage

Tenant agreements/relationships with market tenants

Parking for customers

Access to public restrooms

Utilities (e.g., electricity, water)

Certified processing/kitchen facilities

Waste management

Other (please explain): 
27. What types of market assistance do you believe would help your market's producers/vendors increase their sales? (Please select three items and rank them 1 to 3, with 1 being the most important.)

Research on local customer demographics and preference

Improvements in layout of facility

Renovation of aging facility

__ Training on how to better target consumers

Training on business plan development

Support/funding for producer/vendor advertising and publicity

Training on merchandising/retail displays

Support/funding for local food promotion campaigns

Other (please explain):

28. Which of the following statements about your market was MOST true in 2012?

We have more demand than supply (we need more producers/vendors)

We have more supply than demand (we need more customers)

Our supply and demand are roughly equal (current vendors are meeting the needs of current customers)

\section{PART 3 -- PRODUCER/VENDOR INFORMATION}

29. Do producers/vendors at your market participate in the Women, Infants, and Children (WIC) Farmers Market Nutrition Program?

Yes

No (skip to question 33)

30. How many producers/vendors at your market participated in the WIC Farmers Market Nutrition Program in 2012?

31. What was the value of WIC Farmers Market Nutrition Program sales at your market in 2012? $\$$

32. Do producers/vendors at your market participate in the Senior Farmers Market Nutrition Program?

Yes

No (skip to question 35) 
33. How many producers/vendors at your market participated in the Senior Farmers Market Nutrition Program in 2012?

34. What was the value of Senior Farmers Market Nutrition Program sales at your market in 2012 ?

$\$$

35. Do producers/vendors at your market accept SNAP using Electronic Benefits Transfer (EBT) technology?

Yes

No (skip to question 38)

36. How many producers/vendors at your market participated in EBT sales in 2012?

37. What was the value of EBT sales at your market in 2012 ?

$\$$

38. Does your market accept credit/debit cards?

Yes

No

\section{PART 4 - MARKET MANAGER}

39. Does the market manager have a written job description?

Yes

No

40. Which of the following written documents does your market have? (check all that apply)

Constitution

By-Laws

Market Rules

Grievance Policy

Product List 
41. What are the duties of the market manager? (check all that apply)

Farm inspections

Collecting data (e.g., customer counts, products sold)

Operating EBT machine

Public relations spokesperson for the market

Settling disputes, handling problems

Assigning vendor spaces in the market

Opening and closing the market

Advertising (e.g., designing, placing ads, writing, radio spots)

Writing grants

Keeping financial records

Dealing with regulations (e.g., health, agricultural, state, county, city)

Managing websites, newsletter, social media

Promoting food safety

Other (please explain):

42. What is the gender of your market manager?

Male
Female

43. What is the age of your market manager

Under 20

21- 30

31- 40

$41-50$

$51-60$

60 and over 
44. How many years of market manager experience does your market manager have? Less than one year

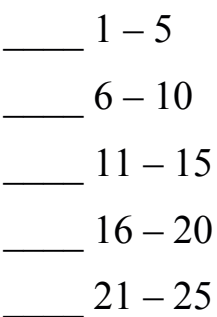

Over 25

45. Please indicate your market manager's highest degree.

Less than a high school diploma

High school diploma or equivalent

_ Bachelor's degree

_ Master's degree

Doctoral degree

Other (please specify

46. Please indicate the amount your market pays to your manager.

\begin{tabular}{l} 
Unpaid \\
Less than $\$ 1,000$ \\
$\$ 1,001$ to $\$ 2000$ \\
$\$ 2,001$ to $\$ 3,000$ \\
$\$ 3,001$ to $\$ 4,000$ \\
$\$ 4,001$ to $\$ 5,000$ \\
$\quad \$ 5,001$ to $\$ 10,000$ \\
\hline
\end{tabular}

47. Does the market manager have the authority to enforce the market rules?

Yes

No 
48. Which of the following does the manager use to get information or advice? (check all that apply)

Local county extension agent

WV Small Farm Conference

WV Farmers Market Association

Local economic development organization

Health Department

Local government agencies

WV Department of Agriculture

49. Is the market manager involved in supplying the demographic, economic, and housing data on new market locations when selecting a new site?

Yes

No

\section{Comments:}




\section{APPENDIX G}

Questions Comments 
Question \#4: How did your market finance its operations in 2012?

- $45 \%$ fundraiser $/ 25 \%$ corporate sponsor

- Flex-E-Grant

- sales + commissions

- $0 \%$

- received \$250 for participating in Oglebay Farm to Table

- no income

- no expenses

- usda fmpp grant yr 2 of 2

- donations and fundraiser sales

- MGMWV+ Private

- Hometown Hardware Store

- we have no expenses

- we paid our self

- at fairgrounds, no charge to use

- WFM Pilot Grant

- Manager

- we have no funding

- no finance

- Grant funding

Question \#8: Please indicate the number of producers/vendors, who sold products at your market in 2012.

- $\operatorname{artisans}$

- soaps/lotions

- pottery

- charcoal

- rada products

- fine art

- soaps, lotion, bath salts

- grains

- skin care products

- tupperware/partylite/Lia Sophia

- health professionals

- teas

- photography

- bath \& body 
Question \#9: What labels are used by producers/vendors to sell products?

- WV Grown

- Bakers have allergy notice on table

- homemade bakery

- WV Grown

- Ingredient labels

- No chemicals used in our gardens

Question \#11: Please rank the top three reasons why you believe customers shopped at your market in 2012.

- gathering place for family \& friends

- live music, prepared food, art

- our location

- use of senior vouchers

- location of market

- access to WIC and senior citizen vouchers

- Availability of food in community with no grocery store

Question \#14: Please rate each of the following methods of advertising that your market currently uses.

- participation in other community events

- word of mouth

- co-market sale

- mail out post cards at opening

- recycled bags

- advertised at other farmers markets in area

Question \#25: Please rank the top three operational issues that need improvement in your market.

- fundraising for expansion

- development of management board and fees to pay manager

- none known

- ability to take food stamps

- more vendors to have a variety of products offered

- due to significant increase in volume due to high tunnel production-- space for expansion is necessary 
- vendor count/participation

- more space for market

- everybody sells out normally

- vendor number

- more producers 2. more variety of produce

- vendor recruitment

- number of vendors

- market coordinator

- Vendors! No farmers want to drive down into Montgomery

Question \#26: Who develops rules, regulations, and producer/vendor criteria for your market?

- project manager

- extension service

- county health dept.

- decisions made by producers twice a year

- city \& county have membership on board

- extension agent

- none

- consensus, we used WVFMA as a guide

- no one

- MFM Board

- Master Gardeners

Question \#27: What types of market assistance do you believe would help your market's producers/vendors increase their sales?

- $\quad$ sustain the market to stop grant funds

- paid market manager that isn't also selling

- activity at the market- chef/music

- there is not much that would help the Sutton Market, same customers return faithful each week

- funding to support low tunnels/insurance pool for markets and vendors

- we need more and younger vendors

- each vendor sells as much as he/she can raise. Need more farmers selling corn \& $1 / 2$ runner beans

- full time year round facility offering regular hours/ 6 days a week

- Strengthening of local farms so they will have excess to sale 
Question \#41: What are the duties of the market manager?

- all managed by volunteer bd of directors

- convene meetings

- sharing recipes, finding guests to attend/perform/educate/etc.

\section{Question \#50: Comments}

The survey participants were provided a blank space to just list their comments and the following is their comments:

- The Market is "managed" by the vendors in attendance at each market. They primarily only set up a barricade to block traffic in the vendor area of the parking lot. Some support is provided by WVU Extension and Main Street program to select opening \& closing dates of market $\&$ help with publicity.

* We are a year round market with online ordering option. www.monroefarmmarket.com

* Ext agent has served as manager in recent years.

* Our market may well collapse: 1)vendors can't afford \$300 for Insurance, 2)vendors can't afford to become LLCs, 3)vendors will not participate in EBT/SNAP if it means receiving a 1099, 4)market cannot afford a market Mgr. (if it will ever exist again!) nor the 50\% cost share of a Vista, 5) More WVDA \& Health Dept. regulations will force more dropouts

* We are a small market. Made up of older ladies. We enjoy the market. Sell home grown vegetables \& fruits. Our biggest need is for younger farmers to get interested in picking up where we started and continue.

* AmeriCorps Vista paid position 
Our producers are local folks who have large gardens, we do not have any farmers producing veg \& fruits, we would like to see $\&$ encourage younger folks get into this area of production. We have livestock and poultry producers.

* Open 6 days per week

* I am market manager because no one else comes every week and I volunteered to do so. I missed the meeting last year that said we needed to collect data from the market from the farmers. Some believe that it is confidential what they make. I will try to do better with statistics this year.

* Ext agent is market manager currently

* As a young market, the situation is evolving, we are incorporating as a non-profit, EBT, music series...

* Operates 4 days a week

extension agent is manager

Market Mgr. is a volunteer--Little to no cooperation from the vendors on supplying info about what coming to market--City Mgr. sees the market as a determinant to the city

* We are not a fresh produce market, we are a stockyard. We have a misc. auction to sell chickens, small animals \& produce, then livestock.

unpaid position

We would love support on having our own market and how to link with new community garden

* We have a great need for fresh, local produce in Montgomery; we have very little interest in any producers driving here to participate in our farm market. One 
vendor that does come picks up produce or buys it. Board is not happy with the situation and does not enforce the rules because they would run off their only vendor.

* Our markets began with the Tyler County Master Gardeners to encourage "Buy Local"--We received a grant this year to hire a $\mathrm{P} / \mathrm{T}$ market manager. We hope to improve participation by both vendors and customers. 
VITA

West Virginia University, Master of Science Degree 1976, Major in Agriculture Economics

Glenville State College, Bachelor of Science Degree, 1974, Major in Biology

Gilmer County High School, General Studies Degree, 1970 